UNIVERSIDADE FEDERAL DE SANTA CATARINA

Programa de Pós-Graduação em Engenharia Ambiental

Cristiano Jorge Faria de Sousa

VIABILIDADE ECONÔMICO-AMBIENTAL DA SUBSTITUIÇÃO DO COQUE UTILIZADO EM ALTO-FORNO PARA OBTENÇÃO DO FERRO GUSA: ESTUDO DE CASO

Florianópolis

2015 
Cristiano Jorge Faria de Sousa

\section{VIABILIDADE ECONÔMICO-AMBIENTAL DA SUBSTITUIÇÃO DO COQUE UTILIZADO EM ALTO-FORNO PARA OBTENÇÃO DO FERRO GUSA: ESTUDO DE CASO}

Dissertação submetida ao Programa de Pós-Graduação da Universidade Federal de Santa Catarina para obtenção do Grau de Mestre em Engenharia Ambiental.

Orientador: Prof. Dr. Joel Dias da Silva

Florianópolis

2015 
SOUSA, Cristiano Jorge Faria de. Viabilidade econômico-ambiental da substituição do coque utilizado em alto-forno para obtenção do ferro gusa: estudo de caso.

Cristiano Jorge Faria de Sousa. Santa Catarina 2015.

Orientador: Prof. Dr. Joel dias da Silva Dissertação (mestrado) Universidade Federal de Santa Catarina, Programa de Pós-Graduação em Engenharia Ambiental.

1. Siderurgia. 2. Coque. 3. Impactos Ambientais. 4. Sustentabilidade. 


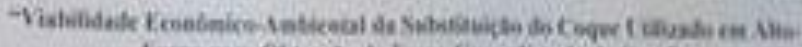

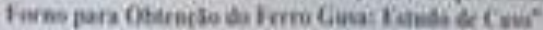

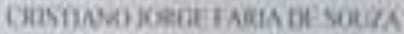

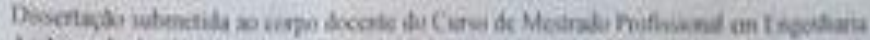

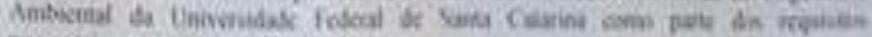

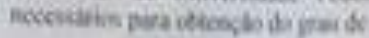

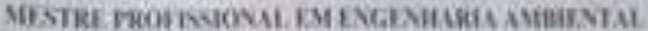

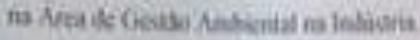

Apansoper:
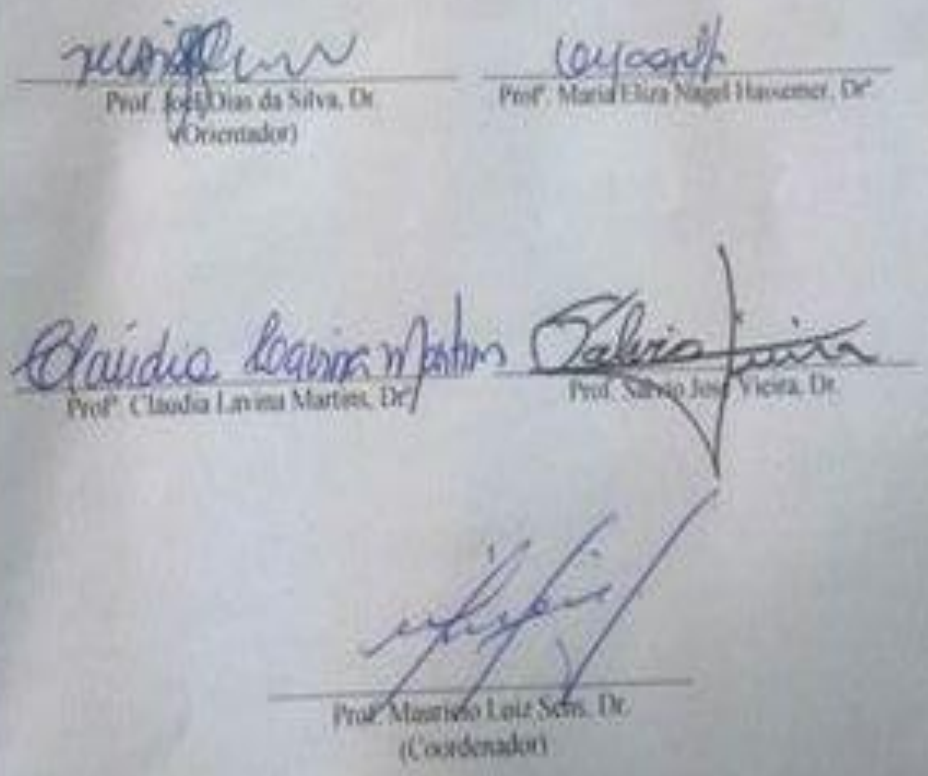

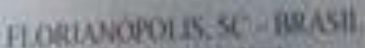

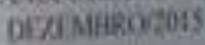


A minha Família, pelo incentivo e carinho. 


\section{AGRADECIMENTOS}

Ao Professor Joel Dias da Silva, pela orientação, pelo aprendizado e apoio em todos os momentos necessários.

A minha família, pela compreensão, nas horas que chorei e nas horas que sorri nas horas que me lamentei e nas horas que de uma forma ou de outra demonstrei total alegria... O desânimo tentou se apossar por vezes... Entretanto, ao lembrar de suas faces preocupadas no correr destes anos, de suas orações, de seu apoio incondicional, me impulsionou deveras para a luta.

A Universidade Federal de Santa Catarina, pela rica troca de experiência.

Aos meus amigos, por nunca me deixarem só. É bom saber que temos amigos em quem podemos confiar. Pessoas que nos apoiam e nos acolhem com tanto carinho dando-me palavras de conforto e ânimo.

A todos, que de alguma forma, contribuíram para a realização deste trabalho, fica expressa aqui a minha gratidão. 
Quando o homem aprender a respeitar até o menor ser da criação, seja animal ou vegetal, ninguém precisará ensiná-lo a amar seu semelhante.

Albert Schwweitzer (Nobel da Paz 1952) 


\section{RESUMO}

O coque é um tipo de combustível obtido a partir do aquecimento do carvão betuminoso ou da hulha em um recipiente fechado, sem a necessidade de combustão e pode ser usado na produção de ferro-gusa, apenas com a sua adição à carga metálica. Diante do exposto, o objetivo desse trabalho é realizar uma avaliação econômico-ambiental da substituição do coque utilizado em alto-forno em uma indústria siderúrgica localizada no Vale do Aço, em Minas Gerais. A metodologia adotada foi um estudo de caso para a comparação da viabilidade econômico-ambiental entre o gás natural e o carvão vegetal em relação ao coque utilizado no alto forno 2 da usina siderúrgica da região de Timóteo levando-se em consideração as quantidades consumidas destes para produção de 1 tonelada de ferro gusa. A utilização da Matriz de Leopold permitiu constatar que os impactos ambientais causados no processo de beneficiamento do carvão vegetal é alto, pois gera expressiva quantidade de poluentes, tais como ácido acético, metanol, alcatrão solúvel e insolúvel e outros. Por isso, a sistematização de uma metodologia para avaliar os impactos ambientais como a Matriz de Leopold é fundamental, pois facilita a visualização dos possíveis impactos de determinado empreendimento e possibilita a realização de um estudo de impacto, inclusive, de vizinhança, de forma rápida e eficaz. Com base nos resultados obtidos, concluiu-se que mesmo sendo o coque um combustível que gera mais energia e retorno financeiro, implica também em degradação intensa no meio ambiente. Já o gás natural e o carvão vegetal, mesmo não possuindo a qualidade energética do coque, prejudicam menos o meio ambiente, pois os gases que soltam não são tão poluentes e conseguem atingir ou se aproximar dos limites de tolerância impostos pelos órgãos ambientais.

Palavras-chave: Siderurgia. Coque. Impactos ambientais. Sustentabilidade. Carvão vegeral. Gás natural. 


\begin{abstract}
The coke is a type of fuel obtained from heating coal shale or coal in a closed container, without the need for combustion. In addition, it can be used in the production of pig iron, only with its addition to the metal load. Given the above, the objective of this work is to make an economic and environmental assessment of the replacement of the coke used in blast furnace at a steel industry located in the Steel Valley, Minas Gerais. The methodology used was a case study to compare the economic and environmental feasibility of natural gas and charcoal in relation to the coke used in blast furnace 2 of the steel plant Timothy region taking into account the quantities consumed these to production of 1 ton of pig iron. The use of Leopold Matrix allowed to establish that the environmental impacts on charcoal beneficiation process is high because it generates significant amounts of pollutants such as acetic acid, methanol, soluble and insoluble tar and others. Therefore, the systematization of a methodology to assess the environmental impacts such as the Leopold Matrix is important because it facilitates the visualization of possible specific project impacts and enables the performance of an impact assessment, including neighborhood, quickly and effective. Based on the obtained results, it is concluded that even though the coke fuel that produces more energy and financial return, also involves rapid degradation in the environment. Since natural gas and charcoal, while not having the energy quality of coke, less harm the environment because the gases are not as loose and pollutants can reach or approach the tolerance limits imposed by environmental agencies.
\end{abstract}

Keywords: Steel. Coke. Environmental impacts. Sustainability. 


\section{LISTA DE FIGURAS}

Figura 1- Esquema resumido de uma usina integrada operando com uma coqueria.........................................................

Figura 2- Vista geral de um forno e câmara de coqueificação aberta, no detalhe, prestes a ser descarregada........................................................ 27

Figura 3- Produtos e subprodutos da coqueificação....................... 28

Figura 4- Desenfornamento do coque nos fornos.......................... 30

Figura 5- Unidade "cracking" termico de coque............................ 31

Figura 6- Custo de utilização...................................................... 5

Figura 7- Custo de utilização.................................................... 56

Figura 8- Massa de gás em $\mathrm{kg}$ por tonelada de lenha beneficiada............................................................... 60

Figura 9- Massa de gás em kg por tonelada de carvão mineral beneficiado na coqueificação...................................... 62 


\section{LISTA DE TABELAS}

Tabela 1- Composição típica do alcatrão e temperatura de destilação.

Tabela 2- $\quad$ Derivados de óleos leves e seus átomos de carbono... 34

Tabela 3- Composição do gás de coqueria purificado................ 41

Tabela 4- Limite máximo permitido de algumas substâncias no gás de coqueria............................................................ 42

Tabela 5- Concentrações e pH de contaminantes nos efluentes da coqueria.

Tabela 6- Efluentes da lavagem e resfriamento do gás e do apagamento do coque.

Tabela 7- Limites máximos de emissões de poluentes atmosférico para coqueria.......................................... 47

Tabela 8- Produtividade e consumo de combustível.................. 53

Tabela 9- $\quad$ Custo da produção do gás natural por estado.............. 54

Tabela 10- Custo da produção da tonelada de carvão vegetal por seguimento financeiro................................................ 56

Tabela 11- Produtos e Emissões da Coqueificação........................ 58

Tabela 12- Produtos e emissões do beneficiamento do carvão vegetal................................................................... 59

Tabela 13- Emissões da coqueificação por tonelada de carvão.... 61

Tabela 14- Diferenciação por letras minúsculas das substâncias emitida na coqueificação............................................ 63

Tabela 15- Classificação de cada constituinte emitido na coqueria.

Tabela 16- Diferenciação por letras minúsculas das substâncias emitidas no beneficiamento do carvão vegetal.......... 64

Tabela 17- Classificação de cada constituinte emitido no beneficiamento do carvão vegetal 


\section{LISTA DE SIGLAS E ABREVIATURAS}

BNDES- Banco Nacional de Desenvolvimento Econômico e Social

CNI- Confederação Nacional Da Indústria

CNTP- Condições Normais de Temperatura e Pressão

CONAMA- Conselho Nacional do Meio Ambiente

CTG- Coal-to-Gas

DBO- Demanda Bioquímica de Oxigênio

DQO- Demanda Química de Oxigênio

DRI- Direct Reduction Iron

EPE- $\quad$ Empresa de Pesquisa Energética

GEE- Gases do Efeito Estufa

GLP- Gás Liquefeito de Petróleo

HBI- Hot Briquette Iron

IBS- Instituto Brasileiro de Siderurgia

MDC- $\quad$ Emissões de Gases Estufa

PIB- Produto Interno Bruto

TSD- $\quad$ Total de Sólidos Dissolvidos

TSS- Total de Sólidos em Suspensão

UCR- Unidades de Coqueamento Retardado 


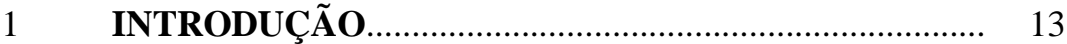

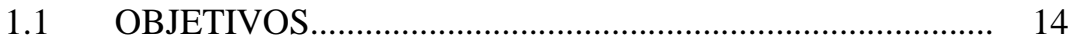

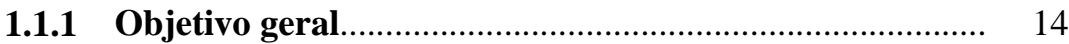

1.1.2 Objetivos específicos...................................................... 14

2 REVISÃO BIBLIOGRÁFICA ......................................... 15

2.1 A SIDERURGIA BRASILEIRA.......................................... 15

2.2 O GÁS NATURAL........................................................ 20

2.3 O CARVÃO VEGETAL .................................................... 21

2.3.1 Carbonização................................................................. 24

2.3.2 Produtos e subprodutos do processo de coqueificação..... 26

2.4 O COQUE.................................................................. 28

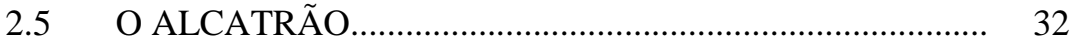

2.6 ÓLEOS LEVES............................................................... 34

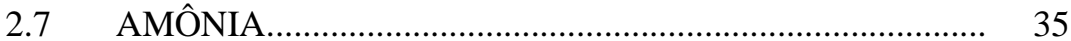

2.7.1 Sulfato de amônio............................................................. 38

2.8 GÁS COMBUSTÍVEL................................................... 39

2.9 EFLUENTES LÍQUIDOS................................................ 42

2.10 EFLUENTES GASOSOS.................................................. 45

3 METODOLOGIA ...................................................... 48

3.1 PROCEDIMENTOS METODOLÓGICOS........................... 48

$4 \quad$ RESULTADOS E DISCUSSÃO ….................................. 53

4.1 COMPARAÇÃO DA VIABILIDADE ECONÔMICA......... 53

4.1.1 Comparação da viabilidade econômica entre o gás natural e o coque.............................................................. 53

4.1.2 Comparação da viabilidade econômica entre o carvão vegetal e o coque................................................................ 55

4.2 COMPARAÇÃO DA VIABILIDADE AMBIENTAL..... 57

4.2.1 Comparação da viabilidade ambiental entre o gás natural e o coque........................................................... 57

4.2.2 Comparação da viabilidade ambiental entre o carvão vegetal e o coque............................................................... 58

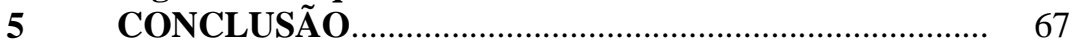

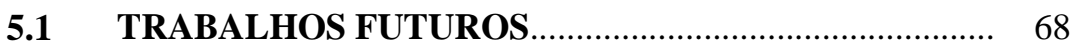

REFERÊNCIAS ................................................... 69 


\section{INTRODUÇÃO}

No início da década de 1990, por conta da baixa demanda de aço, a produção siderúrgica preencheu cerca de $65 \%$ de sua capacidade instalada. Neste ano, a produção brasileira de aço bruto foi de 20,6 milhões de toneladas. Sob forte apoio do Banco Nacional de Desenvolvimento Econômico e Social (BNDES), entre 1994 e 2001, houve uma série de investimentos na modernização do parque nacional siderúrgico, mais especificamente nas fases tecnológicas de redução, aciaria, lingotamento e laminação, além de investimentos em meio ambiente (IBS, 2009; ANDRADE; CUNHA, 2005).

Com a evolução da produção física, houve um ganho de participação do Brasil na América Latina entre 1970 e 1980 e com isso o país passou a representar cerca de $50 \%$ da produção desta região (WSA/ILAFA/IBS in IBS, 2009).

Contudo, as indústrias siderúrgicas têm gerado impactos ambientais decorrente das suas atividades proveniente das emissões das coquerias, especialmente nas etapas de manuseio do carvão, do enfornamento, carbonização, combustão, desenfornamento, apagamento do coque e por fim, da purificação do gás de exaustão (SANTOS, 2010).

Nos altos-fornos, o coque é utilizado como redutor do minério de ferro e, quando colocado nos altos-fornos, é feita uma combustão incompleta, que libera energia e monóxido de carbono (CO) que, em um meio com hematita e altas temperaturas, reage com o oxigênio presente no $\mathrm{Fe}_{2} \mathrm{O}_{3}$ para gerar dióxido de carbono $\left(\mathrm{CO}_{2}\right)$ e formar ferro gusa (PIERONI; GUERRA; SANTOS, 2004).

Devido a isso, exige-se do carvão baixa reatividade e alta resistência física de maneira que não se degrade até a zona inferior do forno (ARAÚJO, 1997). "A qualidade do coque pode ser definida como sendo a sua capacidade de preencher os requisitos básicos dele exigidos no alto-forno" (CARNEIRO, 2012, p. 2). Mas, há um processo alternativo para a produção do gusa líquido conhecido como Corex, com diversas unidades operando no mundo.

Os processos de redução direta, na sua maioria, necessitam do gás natural como combustível (JACOMINO et al, 2002). O motivo desta mudança está totalmente ligado ao que a sociedade e o mundo vê como um sério problema a ser abordado e tratado: a enorme degradação ambiental que o processo de produção do coque gera (SANTOS, 2010), sem se mencionar saldo gerado para as siderúrgicas através de pesadas multas e a imposição de limites de controle cada vez mais rígidos por parte de órgãos ambientais. Esta nova realidade fez com que a indústria 
siderúrgica migrasse, mesmo que a passos lentos, para outras formas de combustíveis redutores que pulem a etapa de beneficiamento da matéria prima que é a etapa mais poluente do processo (ARAÚJO, 1997).

Com base no exposto, o objetivo deste trabalho é avaliar a viabilidade econômico-ambiental da substituição do coque por combustíveis como o gás natural e o carvão vegetal em um dos altos fornos de indústria siderúrgica do Vale do Aço mineiro.

Diante deste quadro, o interesse por combustíveis menos poluentes tem colocado diversos deles para análise de eficiência química e da viabilidade econômico-ambiental. Dentre eles, o gás natural e o carvão vegetal que são alvos deste estudo.

\subsection{OBJETIVOS}

\subsubsection{Objetivo geral}

Realizar uma avaliação econômico-ambiental da substituição do coque utilizado em alto-forno em uma indústria siderúrgica localizada no Vale do Aço, em Minas Gerais, pelo gás natural e carvão vegetal para produção do ferro gusa.

\subsubsection{Objetivos específicos}

a) buscar embasamento teórico de trabalhos que valorizem a sustentabilidade dos processos industriais, especialmente aqueles que contemplassem a substituição de combustíveis poluentes;

b) aplicar a Matriz de Leopold para confrontar os impactos causados pelo gás natural e o carvão vegeral;

c) fazer um levantamento dos aspectos ambientais utilizando a Matriz de Leopold e econômicos da utilização do coque no processo principal; 


\section{REVISÃO BIBLIOGRÁFICA}

\subsection{A SIDERURGIA BRASILEIRA}

Segundo PWC (2013), o Brasil está no $9^{\circ}$ lugar como maior produtor mundial de aço, colocando-o em uma posição de grande estratégia neste cenário. Somente no ano de 2012, foram produzidos em média 34,5 milhões de toneladas de aço e, com isso, fez com que o país fosse o responsável por $4 \%$ do PIB nacional. No ano de 2011, a indústria do aço brasileira foi responsável por $12,9 \%$ do superávit da balança comercial, se recuperando de um saldo de US\$ 337,1 milhões em 2010.

De acordo com a CNI (2012), o parque produtor de aço no Brasil está distribuído em dez estados, dentre eles, Minas Gerais, São Paulo, Espírito Santo e Rio de Janeiro, correspondendo a $94 \%$ do aço produzido e a maior concentração de empresas atuantes no setor.

Ainda conforme a CNI (2012), na América do Sul, o Brasil possui o maior parque industrial de aço, constituído por 29 usinas, sendo ele também o maior país produtor da América Latina e ocupa o $7^{\circ}$ lugar em exportação de líquido de aço.

Contudo, no Brasil, esse parque ainda é relativamente novo e, por isso, tem passado por constantes processos de atualização tecnológica. Ainda assim, o Brasil tem capacidade para exportar aço para aproximadamente 100 países, tendo como maior concorrente, a China, líder do mundial no mercado de aço (CNI, 2012).

De acordo com o PWC (2013), entre os anos de 1994 a 2011, no Brasil houve um investimento na indústria siderúrgica de US\$ 36,4 bilhões, priorizando a modernização e a atualização tecnológica das usinas o que permitiu o alcance de uma capacidade instalada de 48 milhões de toneladas.

Atualmente, é possível caracterizar o mercado de aço a partir de uma situação de oferta e da diminuição das margens, mas não somente no Brasil, mas em todo o mundo. No caso brasileiro, a produção de aço bruto somente no ano de 2013, foi de 34,2 milhões de toneladas. Devido ao fato da capacidade instalada ser de 48,5 milhões de toneladas no país, a indústria siderúrgica operou com a capacidade instalada de $70 \%$, inferior à média mundial, que foi de 74\% (BNDES, 2014).

No caso do coque, Carneiro (2012) explica que o seu uso pelas indústrias siderúrgicas brasileiras de médio e grande porte é hoje imprescindível, sob alguns pontos de vistas operacionais. Pontos de vista estes, que são o seu alto poder energético, seu alto teor de carbono 
e sua elevada resistência mecânica o que propicia sua utilização em grandes altos fornos sem que haja quebra e esmagamento dos grãos de coque devido ao peso.

Além disso, durante o processo de beneficiamento do carvão mineral que dá origem ao coque há a produção de gases. Dentre tais gases, pode-se citar o gás de coqueria de elevado interesse na siderurgia devido ao seu alto poder calorífico sendo utilizado como gás combustível e também óleos leves como benzeno, tolueno e xileno, estes também de muito interesse na utilização nos processos siderúrgicos que envolvam queima e posterior utilização de calor. Apesar destas características vantajosas, a obtenção do coque também é uma gigantesca emissora de outros produtos extremamente nocivos ao meio ambiente e ao homem. Estes produtos são gases poluentes como monóxido de carbono, amônia, dióxido de carbono, sulfetos e cianetos de hidrogênio. Também existem os efluentes líquidos como água contaminada após lavagem do coque incandescente para o resfriamento (CARNEIRO, 2012).

Segundo Costa (2002), tem sido um compromisso de grande parte das indústrias siderúrgicas a adoção de sistemas de gestão ambiental, bem como a certificação de acordo com a norma NBR/ISO 14001. Tal fato tem evidenciado que o setor siderúrgico tem demonstrado preocupação com a preservação ambiental. Além disso, esse compromisso enfatiza a diminuição significativa da utilização de recursos naturais não renováveis, através de uma eficiência maior no consumo desses recursos e melhoria da reciclagem de materiais que são gerados no processo.

Para Vital e Cabral Pinto (2014), tem sido uma busca contínua por parte das empresas siderúrgicas, novas tecnologias de procedimentos e de fontes de energia que proporcionem a diminuição do consumo de energia e, também, o aumento e a melhoria da eficiência energética.

Policarpo (2012) salienta que a utilização da água por parte da indústria siderúrgica tem sido realizada de forma eficiente, pois diversas medidas têm sido adotadas para otimizar a reutilização ou reuso das águas de processo. Desta forma, busca-se diminuir ao máximo o descarte da água e reduzir a necessidade por captação da água dos rios. Conforme o autor, dentre os projetos de sustentabilidade que tem sido adotado no Brasil pelas siderúrgicas, pode-se apontar a proteção e conservação de áreas de mata ciliar, plantio de mudas de árvores nativas em áreas que se encontram em processo de recomposição ambiental, 
proteção de rios que estão fora da área das empresas, criação de Reservas de Proteção ao Patrimônio Natural.

A respeito das emissões atmosféricas, Costa (2002) explica que muitas empresas siderúrgicas fazem o devido monitoramento de emissões de fontes fixas, levando em consideração as emissões de $\mathrm{NO}_{\mathrm{x}}$ (dióxido de nitrogênio), compostos voláteis, $\mathrm{SO}_{\mathrm{x}}$ (dióxido de enxofre), dentre outros.

Observa-se que, no contexto da sustentabilidade ambiental, as siderúrgicas do país parecem estar divididas entre dois opostos: integradas e semi-integradas versus independentes, em especial as produtoras de ferro gusa. O primeiro é representado por 13 empresas privadas, controladas por sete grupos empresariais e operando 25 usinas distribuídas em nove estados (IBS, 2008). Conforme ilustrado no relatório anual do IBS, as fabricantes de aço apresentam ótimos indicadores ambientais: todas atuam para maximizar a eficiência energética, sendo que a geração própria já representa mais de $30 \%$ do consumo total.

A otimização dos recursos naturais é estratégica, e ocorre uma recirculação de $94 \%$ da água utilizada na produção e um reaproveitamento de $94 \%$ dos metais gerados. Já o lado das produtoras de ferro gusa são 69 empresas que possuem 137 altos-fornos instalados, sendo $29,8 \%$ da produção originada de siderúrgicas independentes. O problema de suas relações com o meio-ambiente reside nas estimativas da grande proporção da produção de carvão extraído de matas nativas, o que mostra a contribuição do setor para o aumento da maior fonte emissora de GEE do Brasil: o desmatamento. Dessa forma, com o foco na promoção do carvão vegetal para reduzir tal desnível da sustentabilidade ambiental sugere-se a melhoria de casos menos recomendáveis do setor, tomando como base benchmarks dentre as fabricantes de aço e produtoras de ferro gusa.

Por meio da Figura 1 é possível observar um esquema resumido de uma usina integrada operando com uma coqueria. 
Figura 1 - Esquema resumido de uma usina integrada operando com uma coqueria.

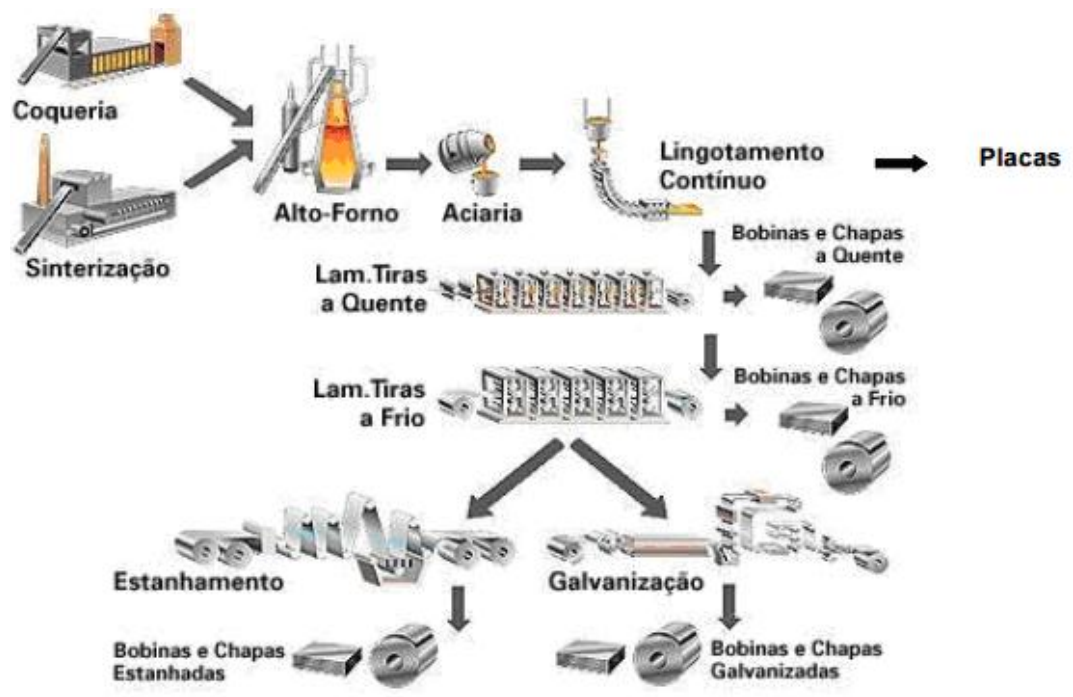

Fonte: MMA, 2015.

Dentre as alternativas para substituir a utilização do coque são, segundo Carneiro (2012), o gás natural e o carvão vegetal. No caso do gás natural, por ser ele produzido nas refinarias de petróleo já chega pronto nas usinas siderúrgicas, eliminando, assim, a necessidade de ser produzido na própria indústria e gerar contaminantes, como é o caso do coque. O carvão de origem de florestas vivas se torna também uma opção por não possuir compostos orgânicos pesados, como é o caso do carvão mineral, fossilizado de onde se extrai o coque. Desta forma, não gera tantos resíduos gasosos poluentes durante o seu processo de beneficiamento.

O processo de beneficiamento do carvão mineral para a produção do coque é denominado quimicamente como pirólise e é na verdade uma destilação fracionada, pois, envolve o aquecimento do carvão a elevadas temperaturas e ausência de ar (COSTA, 2002).

Ulhôa (2005) explica que o carvão mineral é uma massa compacta, estratificada, proveniente da degradação de resíduos vegetais, ou seja, florestas que foram soterradas a milhões de anos atrás e que sofreram um processo de decomposição em consequência de ações geológicas que resultaram em alterações nas suas propriedades físicas e 
químicas. A qualificação de um carvão quanto a sua capacidade de se tornar coque ou não, depende do seu comportamento quando aquecido na ausência de ar. Ao atingir diferentes faixas de temperaturas que correspondem aos pontos de ebulição das diversas substâncias contidas no carvão, estas se volatilizam e formam o gás de coqueria.

Conforme o autor, existem também os compostos líquidos formados durante este aquecimento, compostos estes que são oriundos da quebra de moléculas orgânicas complexas de alto peso molecular formando moléculas mais simples de baixo peso molecular (ULHÔA, 2005).

Além disso, Santos (2010), sinaliza que o aquecimento também forma um resíduo sólido, poroso e infusível constituído de alto teor de carvão. Este resíduo é o coque. O autor explica o aquecimento desse processo, conforme segue:

- Perda de umidade: é a fase em que ocorre a liberação da umidade contida no carvão mineral. Ocorrem em temperaturas que se situam na faixa inicial do aquecimento entre 100 e $120{ }^{\circ} \mathrm{C}$.

- Processo de volatilização inicial que é o início da coqueificação propriamente dita. Ocorre em temperaturas que se situam na faixa de 350 a $550{ }^{\circ} \mathrm{C}$. Nessa etapa ocorre a de alcatrão e hidrocarbonetos pesados.

- Elevação da fluidez. Ocorre na faixa de temperatura que vai de 450 a $600{ }^{\circ} \mathrm{C}$. Nesta etapa o material se torna fluido e pastoso devido a quebra das pontes de hidrogênio que estão presentes em sua estrutura.

- Inchamento. O inchamento ocorre simultaneamente com a fluidez devido à pressão dos gases que estão se expandindo na estrutura porosa do carvão. Sendo assim, ocorre na mesma faixa de temperatura.

- Ressolidificação. É a etapa onde é formado o semicoque, ocorrendo em temperaturas próximas de $700{ }^{\circ} \mathrm{C}$. É fase que geralmente determina a qualidade do coque produzido, pois, uma ressolidificação sem formação de fissuras, garantirá um coque com elevada resistência mecânica, característica esta que é necessária para a utilização do coque em grandes altos fornos uma vez que o coque tem de suportar o peso da carga acima dele.

- Etapa final do processo. Ocorre em temperaturas que se situam na faixa de 850 a $1300{ }^{\circ} \mathrm{C}$. É a etapa onde ocorre a liberação final de gases entre eles o hidrogênio. 


\subsection{O GÁS NATURAL}

Conforme Santos (2010), o gusa é produzido em um alto forno, sendo ele, um produto imediato resultante da redução do minério de ferro pelo carvão ou coque. Geralmente, o gusa possui em média até 5\% de carbono, permitindo-o ser um material quebradiço, sem muitas opções de uso direto.

Diferente do gusa, de acordo com Martinez (2009), inicialmente, o gás natural era considerado uma barreira para a exploração do petróleo e, devido à falta de tecnologia voltada para seu aproveitamento, geralmente ele era queimado quando eram encontrados nos poços de exploração. Isto porque entre transportar para ser aproveitado e queimálo, essa segunda era a alternativa mais barata.

$O$ autor ainda enfatiza que o gás natural se refere a um combustível fóssil que é encontrado em reservatórios subterrâneos, podendo ser em terra ou em mar, associado ou não ao petróleo. Trata-se de uma mistura gasosa de hidrocarbonetos saturados, formado por etano, nitrogênio, butano, dióxido de carbono, propano, pentano em menor quantidade e na maior parte da sua constituição por metano.

Gomes (2006) salienta que geralmente, fala-se que o gás natural é caracterizado como um produto homogêneo. Porém, tal fato apenas ocorre depois que ele é processado e adequado às solicitações requeridas pela demanda, uma vez que, como produto homogêneo, o gás natural se diferencia conforme a localização do seu reservatório de origem. Ainda conforme o autor, há diversas formas de se utilizar o gás natural, tais como, por exemplo, combustível para fornecer calor, para gerar eletricidade, geração de força motriz, como matéria prima em indústrias química, siderúrgica, petroquímica e de fertilizantes.

O gás natural, segundo Pavani (2012), também pode ser usado no transporte em substituição da gasolina, óleo diesel e álcool. Outro uso dessa matéria prima é em segmentos comerciais e industriais, para a produção de água quente, climatização de ambientes e produção de cocção.

Por meio de sua queima, o gás natural é utilizado para aproveitar o conteúdo térmico dos gases após a combustão e, este, pode ser na forma direta ou indireta. No caso da forma direta, faz-se uso dos gases de combustão como fluídos de transferência. Já na forma indireta, esta é estabelecida em decorrência da qualidade do calor que é demandado pelo consumidor final, através do aproveitamento do vapor d'água. 
É possível afirmar que o gás natural de petróleo é a porção de petróleo que existe na fase gasosa ou em solução no óleo, nas condições originais de reservatório, e que permanece no estado gasoso nas CNTP (Condições Normais de Temperatura e Pressão). O gás natural é uma mistura de hidrocarbonetos leves, que à temperatura ambiente e pressão atmosférica, permanece no estado gasoso. É um gás inodoro e incolor, não é toxico e é mais leve que o ar (BRASIL, 2015).

O gás natural é uma fonte de energia limpa, que pode ser usada nas indústrias, substituindo outros combustíveis mais poluentes, como óleos combustíveis, lenha e carvão. Desta forma ele contribui para reduzir o desmatamento e diminuir o tráfego de caminhões que transportam óleos combustíveis para as indústrias. As reservas de gás natural são muito grandes e o combustível possui inúmeras aplicações em nosso dia a dia (BRASIL, 2015).

O gás natural por ser um combustível já encontrado pronto na natureza não necessita de beneficiamento para ser utilizado nas indústrias siderúrgicas. Apesar de causar impactos ambientais como alteração do subsolo para a sua extração e riscos de vazamento dele e de derivados do petróleo durante esta extração assim como no seu transporte para as indústrias, os impactos ambientais não se comparam aos impactos ambientais gerados pelo beneficiamento de outros combustíveis como o carvão mineral e o carvão vegetal.

\subsection{O CARVÃO VEGETAL}

Barcellos (2002) explica que durante a evolução da humanidade, a utilização do carvão vegetal foi se tornando mais intensa. Substituído por combustíveis fósseis em alguns casos, em muitos lares de países subdesenvolvidos ainda é um combustível imprescindível. Para o autor, o homem moderno procura aliar crescimento ao desenvolvimento sustentável desde a utilização de energia a vapor no século XVIII, fato que abriu caminho para a consolidação do uso de energia em escala crescente para a modernidade, passando, nesta busca, pela utilização de fontes como o petróleo e a eletricidade entre outras. A demanda pelo crescimento sustentável tem levado cada vez mais à utilização de energias alternativas renováveis.

Porém, Joaquim (2009) enfatiza que mesmo em alguns países onde o acesso a outras fontes de energia é intenso, o carvão vegetal tem utilidade tecnológica importante, como no caso da produção de certos fundidos de ferro no Brasil que necessitam de matéria prima (ferro gusa) isenta de enxofre, sendo que este elemento químico está presente no carvão mineral. 
O carvão vegetal, até a Segunda Grande Guerra Mundial, era o combustível mais usado em todo o mundo. Contudo, passou a ser relegado como fonte subsidiária de energia em decorrência do surgimento da energia nuclear e da descoberta de combustíveis derivados do petróleo, o qual permitiu ao homem desenvolver motores, obter maiores perspectivas em termos de velocidade e potência (LEAL, 2012).

Entretanto, Joaquim (2009) salienta que o baixo custo que o carvão vegetal possui e a disponibilidade de grandes jazidas ainda fazem com que este seja um combustível que apresenta grande importância na economia mundial.

Em questões ambientais, o carvão vegetal é, segundo Rosa (2010), muito vantajoso se comparado ao carvão mineral, por exemplo, pois é originado de uma fonte renovável. Contudo, os atuais processos que há de carbonização não são livres de poluição, mas, novas tecnologias estão sendo desenvolvidas com a finalidade de promover o aumento desta vantagem ambiental apresentada pelo carvão vegetal.

Para Mota (2013), somente em 1981, por exemplo, em esfera mundial, a produção de aço alcançou 700 milhões de toneladas. Somente na América Latina foram produzidos 27 milhões, sendo que $70 \%$ dessa produção se deve à Argentina, Brasil e México.

Oliveira et al. (2010) explicam que o aumento do uso do carvão vegetal em todo o mundo e, principalmente no Brasil foi marcado por quatro grandes fases distintas. A fase I foi entre os anos 1924 e 1946. Nesse período, a produção de aço no Brasil cresceu de 4,5 mil toneladas para 324 mil toneladas, tendo como principal responsável a Companhia Siderúrgica Belgo Mineira. A taxa média observada de crescimento nessa época foi de $22 \%$ a.a, e a produção se fundamental especialmente, na utilização de insumos nacionais, tal como o carvão vegetal (OLIVEIRA et al., 2010).

A fase II se refere ao período entre 1946 e 1960, quando se iniciava a operação da Companhia Siderúrgica Nacional. A partir de então, começam a ser produzidos laminados planos e da utilização de insumos energéticos importados, em especial, o carvão mineral (OLIVEIRA et al., 2010).

Assis (2008) explica que a fase III data de 1960 a 1964, quando a Usiminas e a Cosipa começaram a produzir aço. A partir de então, a produção de aço cresceu de 1,9 milhões para 3,0 milhões de toneladas, com taxa anual de crescimento de $12 \%$.

Sobre a fase IV, Moraes (2008) salienta que ocorreu de 1964 a 1980. Nesse período, a produção teve uma evolução de 3 milhões de 
toneladas para 15,4 toneladas. A taxa anual de crescimento foi de 8,5\%, com maior concentração na região sudeste, nos estados de Minas Gerais (35\%), São Paulo (32\%) e Rio de Janeiro (24\%).

Quanto à produção de gusa, Mota (2013) salienta que apenas no estado de Minas Gerais há uma concentração de mais de 55\% de toda a produção nacional. De acordo com o autor, é possível dividir o setor siderúrgico em quatro blocos que são as usinas integradas a coque, usinas integradas a carvão vegetal ou redução direta, usinas não integradas e usinas para a produção de gusa. As usinas integradas a coque produzem aproximadamente mais de 55\% do aço bruto nacional. Trata-se de empresas de grande porte que têm capacidade de produção de 3,5 milhões de toneladas/ano/empresa (MOTA, 2013).

Para Barcellos (2002), as usinas integradas a carvão vegetal são aquelas que produzem tubos de ferro fundido e aço, enquanto as usinas não integradas são as responsáveis pela produção de aproximadamente $16 \%$ em todo o Brasil. Sua produção é basicamente constituída por forno elétrico, usando como matéria-prima à sucata. A respeito das usinas para a produção de gusa, o autor afirma que elas produzem exclusivamente o ferro-gusa, com destinação às fundições e aciaria. Neste caso, o insumo mais importante é o carvão vegetal.

Em decorrência das peculiaridades que cada setor siderúrgico apresenta, Leal (2012) afirma que é possível dividir a produção de carvão vegetal em dois cenários que são o de grandes e pequenas produções. Os de grandes produções são, dentre outras, as empresas Acesita, Belgo-Mineira, Mannesmann, Gerdau que produzem aço em grande quantidade. As pequenas produções se referem às práticas em florestas por parte de terceiros ou em pequenas áreas próprias, com caráter predominantemente itinerante (LEAL, 2012).

O Brasil produz aproximadamente um terço da produção mundial e sua quase totalidade é destinada à produção brasileira de ferro gusa, ferro ligas e silício metálico. O uso do carvão vegetal vem mostrar que os aspectos de sustentabilidade deste processo estão no atendimento aos requisitos básicos de ser ambientamente correto e economicamente viável (BRASIL, 2015).

Segundo Assis (2008), o carvão vegetal é proveniente da queima parcial da madeira, obtido a partir da queima ou carbonização da madeira, após este processo resulta em uma substância negra. Na era primitiva, o homem utilizava pedaços de madeira em chamas para iluminar cavernas ou aquecer-se. Posteriormente não tardou a perceber que, ao utilizar a madeira queimada, de aspecto preto e friável, esta não produzia chama e nem tanta fumaça, gerando calor de forma mais 
controlável que aquele produzido pela queima direta da madeira marcando a descoberta do carvão vegetal e seu uso como combustível.

O fogo é utilizado para cocção de alimentos, como fonte de luz e de calor e evolutivamente para o tratamento de materiais que serviriam para confecção de armas, ferramentas e utensílios, conferindo a lenha a qualificação de sistema energético mais antigo da humanidade. (BRASIL, 2015).

\subsubsection{Carbonização}

Para Cemin (2010), a madeira é um dos componentes que, ao ser carbonizado, dá origem ao carvão. A madeira é uma matéria prima constituída basicamente de sais minerais, carbono, nitrogênio, oxigênio e hidrogênio se constituindo em um dos componentes da biomassa de maior utilização energética devido às características benéficas que apresenta, dentre elas, a qualidade a produtividade e massa específica adequada, bem como seu baixo custo.

O processo de carbonização, ainda segundo o autor, se refere a um método químico de combustão incompleta que envolve determinados sólidos quando são colocados ao calor elevado. Como resultado desta reação, o produto gerado é chamado de carvão. Em decorrência da ação do calor, é retirado pela carbonização o oxigênio do sólido e o hidrogênio para que a matéria restante seja constituída principalmente de carbono. Dentre os materiais que podem passar pela carbonização, pode-se citar os polímeros, tais como termofixos, a madeira e tecido biológico.

De acordo com Santos (2007), o resultado de processos naturais (fogo) é a carbonização, mas também pode ser uma reação proposital e controlada usada para fabricar determinados produtos.

Freitas (2000) salienta que a carbonização se trata de uma metodologia em que há parte da queima normal de determinados combustíveis sólidos, como, por exemplo, da madeira. Durante o período da combustão normal, os elementos que evaporam gerados pela pirólise e carbonização são consumidos para dentro das chamas do fogo e, enquanto isso ocorre, há a combustão que pode visivelmente ser observado como carvões ou brasas vermelhas que se queimam mesmo sem a presença de chamas.

Conforme Pinheiro et al. (2006), a carbonização é um processo em que a madeira é submetida ao aquecimento entre 450 e $550{ }^{\circ} \mathrm{C}$ em ambiente fechado, com pequena quantidade ou exclusão total de ar e durante a qual são liberados gases, vapores de água e líquidos orgânicos, 
permanecendo como resíduos, principalmente, o alcatrão e o carvão vegetal. É, portanto, a mitigação das emissões de $\mathrm{CH}^{4}$ no processo de produção do carvão vegetal (carbonização da madeira).

Segundo Rezende (2006), o processo de carbonização do eucalipto ocorre em quatro etapas distintas que são a secagem, a terrefação, a carbonização e a fixação. A secagem ocorre até $110{ }^{\circ} \mathrm{C}$, quando apenas a umidade é liberada. A torrefação ocorre entre 110 e $250{ }^{\circ} \mathrm{C}$, sendo que, na temperatura de $180{ }^{\circ} \mathrm{C}$, tem início a liberação da água de constituição pela decomposição da celulose e hemicelulose. Pouco peso é perdido até $250{ }^{\circ} \mathrm{C}$. Forma-se o tiço ou madeira torrada. A carbonização ocorre entre 250 e $350{ }^{\circ} \mathrm{C}$ e, com a intensificação da decomposição da celulose e hemicelulose, ocorre expressiva perda de peso, formando-se gás, óleo e água. Ao se atingir a temperatura de 350 ${ }^{\circ} \mathrm{C}$, o carvão possui $75 \%$ de carbono fixo considera que a carbonização está praticamente pronta. A fixação é de $350{ }^{\circ} \mathrm{C}$ em diante, ocorre redução gradual na liberação de elementos voláteis, principalmente gases combustíveis, continuando a fixação do carbono.

A carbonização, conforme Sampaio (2001), é uma espécie de destilação fracionada da madeira (semelhante a destilação fracionada que transformava o carvão mineral em coque) e que gera um resíduo rico em carbono, o carvão vegetal, além da liberação de vapores e gases (alcatrão, piro lenhoso e gases não condensáveis). O uso disseminado do carvão vegetal há gerações, por diversos setores, vem permitindo o aprimoramento dos processos de produção. $\mathrm{Na}$ tentativa de melhorar os métodos tradicionais de produção do carvão vegetal, os fornos metálicos têm sido aperfeiçoados visando o alcance de resultados em termos de redução do tempo de carbonização, aumento nos rendimentos volumétricos de madeira por metro de carvão, aproveitamento dos subprodutos do processo, diminuição dos custos logísticos, diminuição na emissão de poluentes entre outros.

No caso dos fornos de alvenaria ou tijolos que fazem parte do processo artesanal de produção de carvão vegetal no Brasil, Pinheiro et al. (2006) afirmam ser responsável por cerca de $70 \%$ do carvão vegetal produzido no país. Estes fornos realizam um ciclo de produção (fornada) a cada seis ou sete dias, podendo chegar a dez dias se a umidade da lenha for elevada. Primeiro, inicia-se o acendimento do forno com o controle da entrada de ar, quando ocorre efetivamente a carbonização. Terminada a carbonização, que dura três dias, o forno é vedado utilizando-se argila e é deixado resfriando até atingir temperaturas da ordem de 40 a $50{ }^{\circ} \mathrm{C}$. Após isto, é realizada a descarga do forno sem o risco da ignição do carvão ao entrar em contato com o ar. 
Considerando a importância do processo de carbonização, Santos (2007) afirma que a utilização energética da biomassa tem sido valorizada como forma alternativa ao uso de combustíveis fósseis, principalmente por ser renovável. Na conversão energética da biomassa (a madeira), faz-se uso de processos termoquímicos, a biomassa da madeira é submetida à ação do calor até transforma-la em compostos mais simples.

Além do exposto, Pinheiro et al. (2006) destacam que a carbonização também tem como finalidade, avaliar a viabilidade econômica do processo artesanal, ou seja, da carbonização feita nos fornos de alvenaria ou tijolos. Os dados da viabilidade financeira são calculados tomando como base a produção anual para um processo produtivo da ordem de 3500 a 4000 MDC (metro de carvão) por mês.

\subsubsection{Produtos e subprodutos do processo de coqueificação}

Segundo Santos (2010), o processo de coqueificação ocorre através do carvão betuminoso ${ }^{1}$. Esse carvão betuminoso possui peculiaridades específicas no processo de pirólise para a geração do coque. O coque, por sua vez, é o produto usado para fabricar ferro gusa nos altos fornos. A peculiaridade específica que o carvão betuminoso tem se refere à sua transformação em coque em decorrência de determinados elementos do carvão, conhecidos como macerais. Quando associados a outros componentes, a quantidade de tais elementos que formam o carvão proporcionará menor ou maior capacidade do carvão em se transformar em coque, juntamente com as propriedades corretas para a utilização em alto forno.

Cavalcanti (2012) afirma que durante o processo de pirólise, destaca-se ainda que as moléculas complexas que constituem o carvão passam por uma decomposição, se transformando em produtos mais voláteis e simples e, quando originado o resíduo sólido, dá-se o nome de coque. Destaca-se, também, que as matérias primas as quais passam pela volatilidade no decorrer do processo são, dentre outros, hidrocarbonetos como, por exemplo, antraceno, metano, naftaleno e crieseno, e elementos como óleos leves e sulfato de amônio alcatrão.

$\mathrm{O}$ autor enfatiza que, a partir de então ocorre a fase plástica, o qual ocorre uma expansão da massa, causando pressão nas paredes. Logo após, ocorre a concentração da massa que é formada. Mais especificamente no processo industrial, o bolo de coque permanece no

${ }^{1}$ Carvão metalúrgico. 
interior do forno por determinado tempo para a formação do coque e para homogeneizar a temperatura da massa de um modo geral. Desta forma, é feita, também, a equalização das propriedades metalúrgicas e físicas do coque.

Além do exposto, é explicado por Morello (2009) que durante o processo de coqueificação acontece a solidificação que se inicia em uma temperatura superior a $500^{\circ} \mathrm{C}$. Durante esse processo, acontecem as volatilizações finais e a constituição do semicoque. A formação dos gases que são gerados vai se modificando por meio do aumento da geração de hidrogênio e diminuição da geração do metano. A temperatura, ao ir elevando cada vez mais, faz com que o semicoque se transforme em coque quando alcançada uma temperatura entre $950^{\circ} \mathrm{C}$ a $1.000^{\circ} \mathrm{C}$, conforme Figura 2.

Figura 2 - Vista geral de um forno e câmara de coqueificação aberta, no detalhe, prestes a ser descarregada

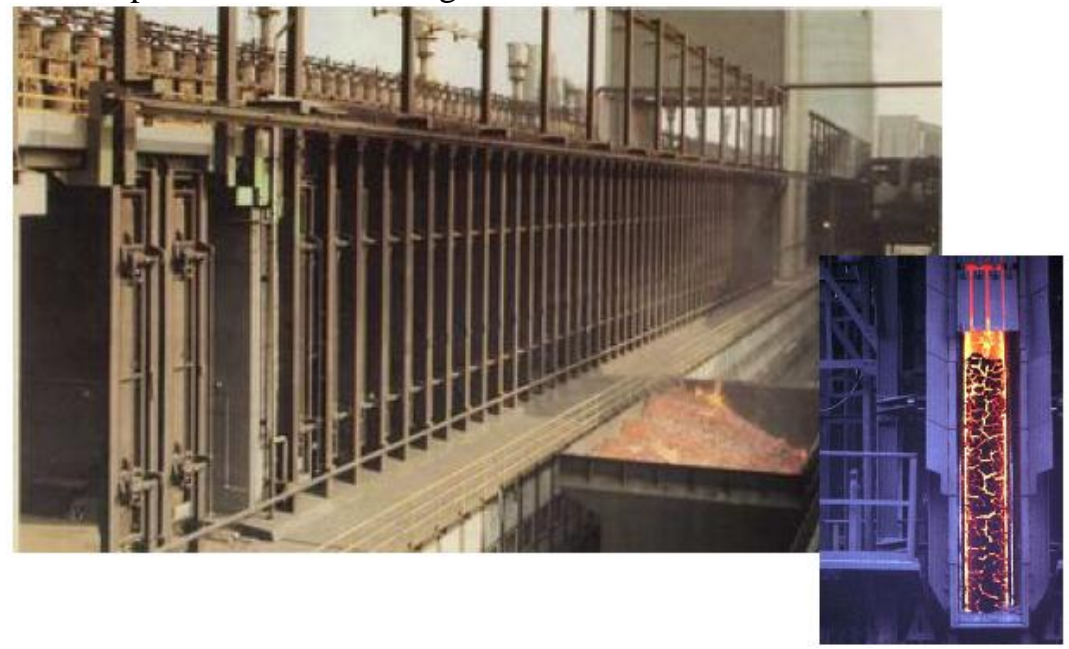

Fonte: Santos, 2010, p. 15.

Conforme Santos (2010), no forno de coqueificação, os subprodutos passam pela estação de tratamentos e, desta forma, por meio do gás de coqueria serão geradas algumas substâncias que, posteriormente, poderão ser aproveitadas em outras áreas da indústria, como o piche, por exemplo. Sobre os subprodutos da coqueria, o autor aponta os óleos leves, o alcatrão, a piridina, o sulfato de amônio e o gás combustível, conforme ilustrado na Figura 3: 
Figura 3 - Produtos e subprodutos da coqueificação

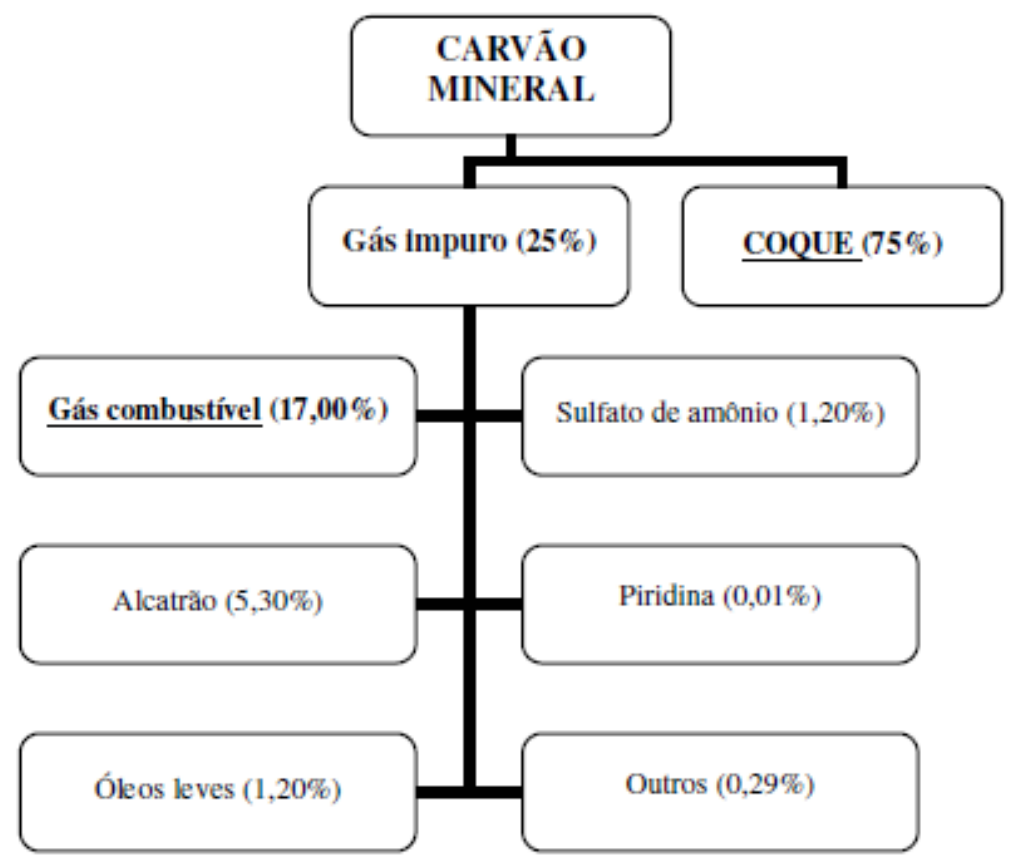

Fonte: Santos, 2010, p. 15.

$\mathrm{O}$ autor ainda enfatiza que no Brasil, os carvões minerais têm pobres propriedades de coqueificação e, por isso, normalmente são misturados em média de 20 a $30 \%$ de carvões importados por apresentarem alta qualidade em comparação ao carvão nacional.

\subsection{O COQUE}

O único combustível que havia até o fim do Século XVII era carvão vegetal, encontrá-lo estava se tornando cada vez mais difícil, o que, por conseguinte, ameaçava o progresso da indústria metalúrgica. Como alternativa, o carvão mineral não era uma alternativa possível, uma vez que ele possui enxofre e este, por sua vez, faz com que o ferro fique quebradiço quando aquecido (FREITAS, SÁNCHEZ e VIEIRA, 2011).

Carneiro (2012) enfatiza que o problema a respeito da falta de carvão vegetal foi solucionado quando surgiu a ideia de queimar em 
local aberto o carvão mineral, da mesma forma como era feito com a lenha para produzir o carvão vegetal. Quando é lentamente aquecido, sem chegar a se queimar, o carvão libera o enxofre e os demais gases voláteis. Esse processo é chamado de coqueificação que, posteriormente, foi aplicado na produção do ferro.

O coque, em pouco tempo, passou a ser usado na produção de ferro utilizado em pilões, potes, grelhas e demais objetos e na produção de cilindros para o motor a vapor de Newcomen. Essa combinação fez com que o carvão passasse a tornar o combustível industrial de maior relevância (CARNEIRO, 2012).

Segundo Caldas (2011), por muitos anos e talvez até a atualidade, a indústria continua dependendo do coque em grande escala, pois ele significa uma considerável parcela do custo final do ferro. É no equipamento chamado de alto forno que ocorre o processo de redução do ferro. Nele é feita a separação do ferro de seu minério que se dá através da diminuição química que envolve o isolamento de um agente redutor e do metal de seu óxido. Esse agente redutor que é usado na siderurgia é o coque.

Conforme Carpío, Silva e Jorge (2003), o coque é o material carbonáceo sólido que pode ser obtido com a destilação do carvão mineral em altos fornos, seguindo determinados critérios, tais como baixo teor de enxofre, ausência de ar, tempo certo e baixo teor de cinzas. A partir da coqueificação do carvão mineral e a otimização da fabricação de ferro, tem-se um importante avanço para a indústria siderúrgica.

Santos (2010) explica que depois de deixar a coqueira, o coque é encaminhado ao alto forno com a função de combustível e gerador do agente redutor. Entretanto, existem determinados padrões de qualidade as quais devem ser consideradas, pois são eles que irão indicar as propriedades física e química para que seja possível utilizar o coque no alto forno.

Por meio da Figura 4 é possível verificar um exemplo de Desenfornamento do coque nos fornos. 
Figura 4 - Desenfornamento do coque nos fornos

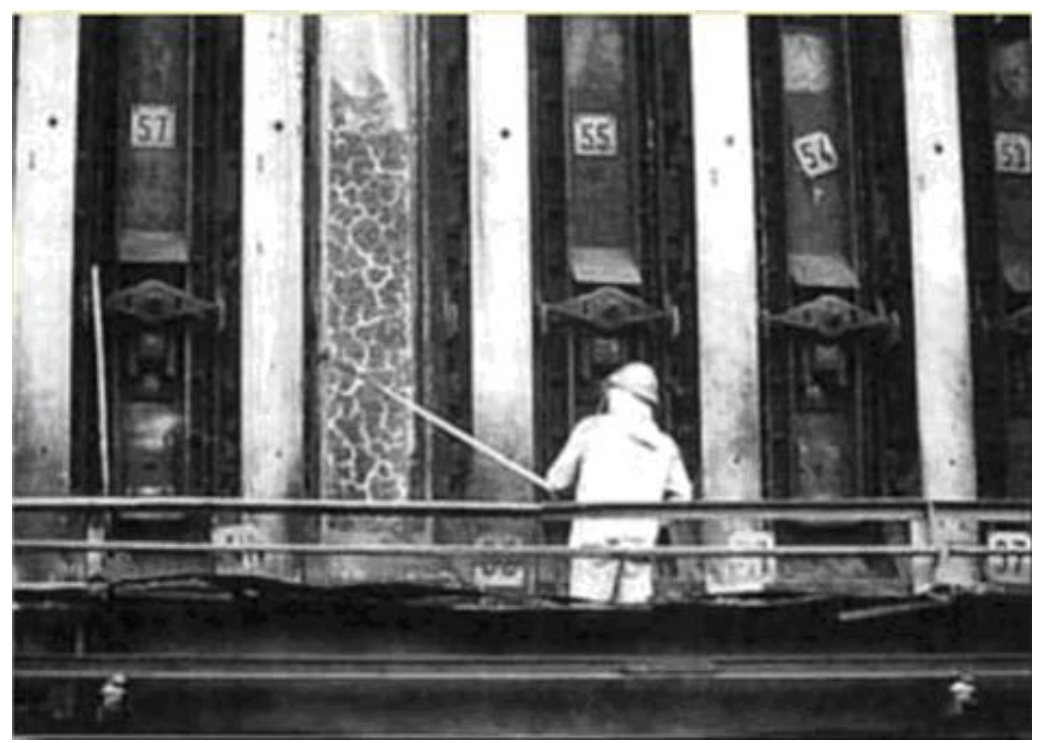

Fonte: Disponível em: <http//:www.cesec.ufpr.br>. Acesso em: 20, out, 2015.

Conforme observado, o coque é um produto sólido, o qual se obtém por meio do craqueamento de óleos residuais pesados em unidades de conversão de resíduos conhecidas como unidades de coqueamento retardado (UCR) (ALMEIDA et al., 2004). Os autores definem o coque como:

Um combustível fóssil sólido, derivado do petróleo, de cor negra e forma aproximadamente granular ou tipo "agulha", e que se obtém como subproduto quando da destilação do petróleo (no fundo da coluna de destilação), num processo designado "cracking" térmico (ALMEIDA et al., 2004, p. 37).

Um exemplo de Unidade "cracking" termico de coque pode ser observado na Figura 5: 
Figura 5 - Unidade "cracking" térmico de coque

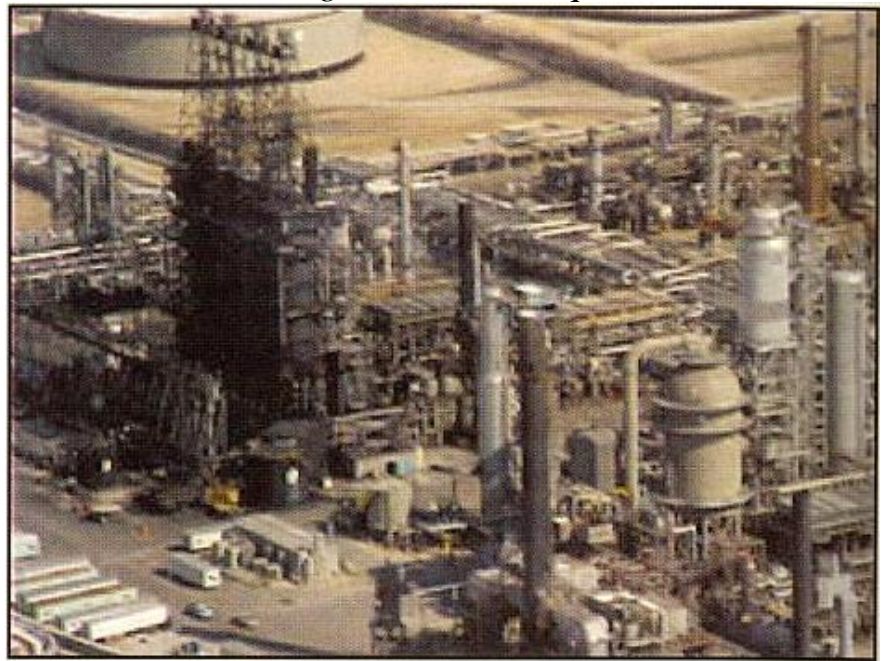

Fonte: Disponível em: 〈http//:www.google.com.br/imagens〉. Acesso em: 12, set, 2015.

Cabrelon et al. (2012) sinalizam que o coque possui características interessantes e importantes para a escolha como combustível quando da escolha pela substituição, a saber o elevado poder calórico; o reduzido teor de cinzas; e o baixo custo de aquisição.

Mas, de acordo com Coelho et al. (2004), dentre os aspectos relevantes para a utilização do coque, existem as suas propriedades e características, as principais aplicações e ainda o que diz respeito ao meio ambiente e à saúde. Quanto às propriedades e características, o coque é composto quase que essencialmente, de carbono fixo e algumas moléculas de hidrocarbonetos de alto peso molecular. Este é obtido a partir do craqueamento de frações residuais pesadas de petróleo.

O coque tem como uma das principais utilizações, ser agente redutor na indústria metalúrgica, e pode inclusive ser utilizado como agente redutor em substituição aos carvões vegetal e mineral (CAMIOTO e REBELATTO, 2014). Além disso, o coque pode ser utilizado também para a produção de coque calcinado de petróleo, fundamental matéria-prima na fabricação de anodo para a indústria de alumínio.

Segundo Freitas, Sanchez e Vieira (2011), o coque é ainda utilizado para fins como cimenteiras, papel e celulose, termoelétricas, ferro-gusa, ferro-ligas, siderurgia, não ferrosos em geral e fundições. No 
que se refere ao meio ambiente e saúde, seu manuseio requer cuidados que se aplicam a produtos sólidos inflamáveis. Deve-se, portanto, mantê-lo longe de fontes de chama e evitar inalação de seus vapores quando o produto é queimado.

De acordo com Caldas (2011), o coque apresenta não apenas características positivas tendo também pontos que são julgados negativos. Além das características gerais positivas que são o elevado poder calórico, o reduzido teor de cinzas e o baixo custo de aquisição, este combustível tem como fundamentos negativos o reduzido teor de materiais voláteis, o elevado teor de enxofre e cinzas contendo metais pesados. Porém, as características positivas levam a empresa a ter alto interesse na utilização do coque verde, sendo que o preço, principal fator da impulsão, é viável.

Quanto às características negativas, Carneiro (2012) afirma que elas implicam em grandes desafios técnicos para a utilização do coque em equipamentos industriais. Por ser um combustível primariamente sólido, os desafios técnicos são particularmente grandes quando se considera a utilização do coque em substituição a combustíveis líquidos e gasosos para equipamentos originalmente projetados para estes.

\subsection{O ALCATRÃO}

São diversas as substâncias que compõem o alcatrão, pois se trata de uma mistura que envolve as betuminosas, com cor escura, espessa e apresenta forte odor. Por meio da destilação de determinadas matérias orgânicas permitem a obtenção do alcatrão, dentre eles, o carvão, madeira resinosa e outros. O alcatrão é muito utilizado e comercializado pelas empresas siderúrgicas (MALINOWSKI, 2013).

Conforme Valentim (2013), a nomenclatura "alcatrão" se deve à semelhança do termo retirado de um derivado do carvão. Além disso, também possui substâncias químicas que podem prejudicar os seres humanos por serem carcinogênicas e resíduos tóxicos.

Ao se queimar o carvão vegetal, tem-se como resultado um resíduo em forma de fumaça e, desta fumaça que se é obtido o alcatrão. $\mathrm{O}$ alcatrão se refere a um produto líquido, mais ou menos viscoso, com cor preta e de composição complexa e variável. A origem do alcatrão, geralmente é da coqueria durante o processo de coqueificação do carvão, uma vez que o carvão tem suas partes voláteis separadas enquanto ocorre o aquecimento constituído de gases. Esse gás, por sua vez, possui determinada quantidade de alcatrão, seja em forma de vapor 
ou outro que, ao ser decantado, forma o alcatrão de Hulha (LEE, LIM e KIM, 2014).

De acordo com Maciel, Andrade e Albuquerque (1996), o alcatrão que é originado de coquerias normalmente é uma mistura de diversos compostos orgânicos e muito complexos, tais como, por exemplo, hidrocarbonetos aromáticos, que podem variar, inclusive, desde piches até substâncias como os óleos leves.

Santos (2010) salienta que é muito comum a comercialização do alcatrão para empresas que fazem seu fracionamento e, também, para produzir a borra do alcatrão, sendo esta uma mistura de partículas de alcatrão e carvão colocadas novamente no processo de coqueificação.

Segundo Lee, Lim e Kim (2014), no que se refere ao alcatrão produzido em coquerias, são envolvidas várias substâncias e muitos compostos aromáticos, dentre eles, naftaleno, benzeno e antraceno, bem como seus derivados (xileno, tolueno e outros).

A Tabela 1 ilustra a composição típica do alcatrão, conforme proposto por Santos (2010):

Tabela 1 - Composição típica do alcatrão e temperatura de destilação

$\begin{array}{ccc}\text { Componente } & \begin{array}{c}\text { Composição em } \\ \text { massa \% }\end{array} & \begin{array}{c}\text { Faixa de Temperatura } \\ \text { de Destilação }{ }^{\circ} \mathbf{C}\end{array}\end{array}$

\begin{tabular}{|c|c|c|}
\hline Água Amonical & $3 \%-8 \%$ & - \\
\hline Óleo leve & $0,5 \%-3 \%$ & Até 170 \\
\hline $\begin{array}{l}\text { Óleos Médios (Fenoís, } \\
\text { Cresóis, naftalenos) }\end{array}$ & $10 \%-16 \%$ & $170-230$ \\
\hline $\begin{array}{l}\text { Óleos Pesados (metil, } \\
\text { dimetil-nafatlenos, } \\
\text { creosotos). }\end{array}$ & $7 \%-10 \%$ & $230-300$ \\
\hline $\begin{array}{l}\text { Piche (óleo pesado, } \\
\text { carbonoso) }\end{array}$ & $8 \%-20 \%$ & $300-400$ \\
\hline Resíduos & $55 \%-60 \%$ & \\
\hline
\end{tabular}

Fonte: Santos, 2010, p. 23.

Sobre o óleo leve do alcatrão, Santos (2010) explica que nele há algum naftaleno e benzeno, contudo, somente no óleo médio são encontradas as frações consideradas mais pesadas dos ácidos do alcatrão, bem como grande parcela do naftaleno. Além disso, o autor ainda sinaliza que o óleo pesado é produzido em uma temperatura de destilação muito elevada e possui carbazol $\left(\mathrm{C}_{6} \mathrm{H}_{4} \mathrm{NHC}_{6} \mathrm{H}_{4}\right)$, naftaleno $\left(\mathrm{C}_{10} \mathrm{H}_{8}\right)$ e antraceno $\left(\mathrm{C}_{6} \mathrm{H}_{4}(\mathrm{CH})_{2} \mathrm{NHC}_{6} \mathrm{H}_{4}\right)$. Quando misturados, os óleos 
pesados e antracênico constitui-se em creosoto, comumente utilizado na impregnação de madeiras.

A respeito do piche, Maciel, Andrade e Albuquerque (1996) enfatizam que este se refere a um resíduo da destilação do alcatrão, apresentando elevada viscosidade. Destaca-se, ainda, que são altos os pontos de ebulição desta mistura de substâncias orgânicas, com importante parcela de carbono livre. Geralmente, o piche é usado na indústria como ligante para fabricar pavimentação de estradas, eletrodos de grafita, gasodutos e impermeabilizante de telhados.

\section{6 ÓLEOS LEVES}

Os óleos leves são também conhecidos como convencionais e, por muitos anos, mantiveram o domínio do cenário de produção na indústria de petróleo, devido ao fato de serem mais fáceis tecnicamente de serem produzidos, por apresentar menor custo, renderem mais após o refinamento e por produzir produtos de alto valor agregado. Dentre tais produtos produzidos a partir de óleos leves, pode-se citar a gasolina querosene, o GLP e o diesel (CATONHO, 2013).

Santos (2010) explica que os óleos leves são mais leves que a água, mas, em sua mistura estão contidos aproximadamente 100 produtos diferentes, contudo, os de maior destaque são, nesta ordem, o benzeno com $65 \%$ a $85 \%$; o tolueno em $5 \%$ a $15 \%$; o xileno entre $2 \%$ e $7 \%$; e nafta solvente com $1 \%$ a $3 \%$.

Para Queiroz (2006), geralmente os óleos leves têm na sua classificação os derivados combustíveis, de acordo com a complexidade das cadeias carbônicas presentes nas moléculas e o comprimento. Desta forma, os óleos leves são aqueles que apresentar as menores cadeias carbônicas, tais como o GLP, o gás combustível, a gasolina e a nafta, conforme segue ilustrado na Tabela 2.

Tabela 2 - Derivados de óleos leves e seus átomos de carbono

\begin{tabular}{cc}
\hline Derivados & Número de átomos de carbono \\
\hline Gás Combustível & 1 e 2 \\
GLP & 3 a 4 \\
Gasolina & 5 a 12 \\
Nafta & 5 a 12 \\
\hline
\end{tabular}

Fonte: Elaborado pelo autor. 
Comumente, os óleos leves também são usados como combustíveis em caldeiras e fornalhas.

Conforme Santos (2010), é importante explicar que os óleos leves são destilados a partir do seu aquecimento e, desta forma, faz-se com que os gases presentes sejam enviados a uma coluna de destilação fracionada. Cada aquecimento tem um intervalo para que determinadas substâncias possam ser recuperadas. Durante o processo de aquecimento, ao atingir uma temperatura inferior a $80{ }^{\circ} \mathrm{C}$, os primeiros produtos a se dissiparem são os "forerunnings", contribuindo com aproximadamente entre $1 \%$ e $2 \%$ do volume total de óleos leves. Esses forerunnings são formados de dissulfeto de carbono e ciclopentadieno.

Entretanto, Catonho (2013) salienta que, ao atingir uma temperatura de $80{ }^{\circ} \mathrm{C}$, ocorre a vaporização do benzol cru, sendo que este representa em média $60 \%$ de todo o volume total dos óleos leves. Quando atinge uma temperatura de $110^{\circ}$, se tem a vaporização do toluol cru e isto contribui em $18 \%$ para o volume total dos óleos leves.

De acordo com Santos (2010), ao chegar a uma temperatura aproximada de $120^{\circ}$ a $125^{\circ}$, ocorre a separação da nafta solvente leve que representa $8 \%$ do total dos óleos leves e, por fim, ao alcançar a temperatura de $150^{\circ}$, a nafta é obtida. No volume total do óleo leve, este solvente pesado representa $6 \%$. Além do exposto, o resultado do resíduo desta destilação é o naftaleno e óleo de lavagem que, ao resfriar se solidificam, representando do total dos óleos leves, 6\%. Comumente, são empregados para fabricar detergentes sintéticos; poliestireno; inseticidas; anilinas; e resinas alquídicas utilizadas em revestimentos.

\subsection{AMÔNIA}

A amônia tem sua fórmula química $\mathrm{NH}_{3}$, por se tratar de um composto químico formado por três átomos de hidrogénio $(\mathrm{H})$ e um átomo de nitrogênio $(\mathrm{N})$ que são distribuídos em uma geometria molecular piramidal. Segundo Felix e Cardoso (2004), a amônia é caracterizada como um gás incolor quando em temperatura ambiente, com um forte odor, além de ser consideravelmente mais leve que o ar. A amônia possui ponto de ebulição de $-77,7^{\circ} \mathrm{C}$ e de fusão em $-33,35^{\circ} \mathrm{C}$, sendo, também muito solúvel em água, isto porque em uma temperatura a $20{ }^{\circ} \mathrm{C}$ e 1 atmosfera, é possível dissolver 702 volumes de amônia em apenas um volume de água, obtendo como resultado uma solução alcalina. A amônia, mesmo sendo facilmente dissolvida na água e pode também ser removida da água com grande facilidade quando levada à fervura. No estado líquido, a amônia é considerada um dos solventes 
mais utilizados para se estudar reações químicas. Comercialmente, a amônia é encontrada em solução aquosa de $15 \mathrm{~mol} \mathrm{~L}^{-1}(28 \% \mathrm{~m} / \mathrm{v})$ em farmácias, drogarias, supermercados, e outros estabelecimentos, com o nome de amoníaco.

Araújo et al. (2009) explicam que a descoberta da Amônia se deu no ano de 1774 , por meio de estudos de Priestley que preparou gásamônia a partir da reação de sal amoníaco com cal virgem com o intuito de recolher o gás formado sobre o mercúrio. Entretanto, no ano de 1784, o estudioso Berthollet realizou a decomposição do gás através de uma centelha elétrica, determinando a composição em três volumes de hidrogênio e um volume de nitrogênio. Acredita-se que, quando surgiu e antes mesmo do advento da indústria de amônia sintética no mundo, tinha-se como principal fonte do derivado nitrogenado (amônia) a constituição a partir dos gases provenientes da coqueificação do carvão.

Segundo Sangoi et al. (2003), considerando a amônia produzida pela coqueificação do carvão, deve-se entender que as emissões da coqueria são compostas por partículas de carbono, fumos de coloração forte e gases que possuem amônia, fenóis, monóxido de carbono, hidrocarbonetos (metano e etileno), dióxido de carbono e sulfeto de hidrogênio. Quanto aos produtos líquidos das emissões da coqueria, estes são os óleos leves como o xileno, benzeno e tolueno, a água e o alcatrão. Dentro da coqueria propriamente dita, as emissões dos gases surgem em decorrência do apagamento do coque, do enfornamento, de vazamento, do desenfornamento e, também, da queima do gás de coqueria que ocorre para aquecer os fornos.

De acordo com Araujo et al. (2009), a amônia, devido à diversidade de propriedades, possui como uma das características a sua ampla aplicação. A amônia pode ser usada para fabricar fertilizantes por servir como fonte de nitrogênio; na indústria do petróleo como agente neutralizador; na indústria como gás de refrigeração, dentre outros. Tais aplicações são possíveis porque a amônia possui um alto poder refrigerante e um potencial muito baixo de destruição do ozônio estratosférico, fazendo com que este gás se torne adequado para ser utilizado, principalmente, em máquinas de refrigeração industrial.

Sobre a amônia na atmosfera, Sangoi et al. (2003) salientam que este gás tem determinado tempo de residência, o qual pode variar aproximadamente entre uma e duas semanas e, posteriormente, ser retirado da atmosfera por processos químicos ou físicos de deposições úmida e seca.

Araújo et al. (2009) afirmam que dentre as principais reações que fazem com que o consumo da amônia gasosa seja motivado está baseado 
na oxidação com composição de $\mathrm{NO}_{\mathrm{x}}$ e com espécies ácidas constituindo partículas secundárias. A amônia está presente em tais partículas, como, por exemplo, o sal de amônio, mas, conforme forem as condições da temperatura e umidade que agem sobre o equilíbrio químico, possivelmente poderá ocorrer interconversão entre essas espécies. Por isso, indica-se que sua representação geral seja sempre como NH.

A respeito do processo de produção de amônia, Felix e Cardoso (2004) explicam que se trata de um grande consumidor de energia térmica e elétrica. Contudo, seu maior consumo está no gás natural, não apenas como matéria-prima, mas inclusive, como combustível para se fazer o preaquecimento de metano, a partir da geração de vapor para que se possa converter a amônia. Dessa forma, a diminuição do consumo de combustíveis fósseis e crescimento da eficácia e eficiência do processo produtivo se voltam para a utilização de novas tecnologias associadas a fornos e queimadores.

Para Santos (2010), no que se refere ao processo de coqueificação, deve-se enfatizar que a amônia tem uma quantidade determinada produzida durante o processo de coqueificação por tonelada de carvão da ordem de 5 a $6 \mathrm{~kg}$. É importante que a amônia seja retirada do gás que se solta devido ao processo de coqueificação mesmo antes que ele seja desbenzoilizado para se recuperar os óleos leves. Tal fato tem por objetivo, evitar que ocorra a rápida deterioração do óleo de lavagem utilizado.

Além do exposto, Santos (2010) ainda salienta sobre a importância de se eliminar a amônia do gás e, para tanto, pode ser feita de dois modos diferentes que são por meio da neutralização direta da amônia, através da utilização de um ácido que, normalmente, é o $\mathrm{H}_{2} \mathrm{SO}_{4}$, como ocorre nos processos direto e semidireto e a produção disso resulta no sulfato de amônio, usado como fertilizante. O segundo modo de eliminação está fundamentado na alta solubilidade apresentada pelo $\mathrm{NH}_{3}$ em água. Neste caso, em apenas um litro de água em temperatura ambiente, se pode facilmente dissolver $530 \mathrm{~g}$ de amônia. Quando no processo indireto, essa eliminação produz o licor amoniacal diluído e, deste se retira a amônia. Esse tem sido o processo que mais alcançou popularidade por apresentar alto valor comercial das águas amoniacais se comparado com o sulfato de amônio. Acerca do processo direto, acredita-se tem se tornado obsoleto, não sendo mais usado. 


\subsubsection{Sulfato de amônio}

$\mathrm{O}$ sulfato de amônio, cuja fórmula química é $\left(\mathrm{NH}_{4}\right)_{2} \mathrm{SO}_{4}$, se apresenta na forma standard e de grânulos brancos com $22 \%$ de enxofre e $20 \%$ de nitrogênio na sua composição. Trata-se de um produto higroscópico, solúvel em água, benzina e álcool (CARVALHO et al., 2010). Conforme Carvalho et al. (2010), o maior uso do sulfato de amônio é como fertilizante, devido ao seu composto inorgânico, pois, é constituído por $21 \%$ ponderal de azoto que se apresenta pela forma amônio e íons e em $24 \%$ de enxofre como iões de sulfato. Como mineral raro, o sulfato de amônio pode surgir naturalmente como resultado da queima de carvão e como mascagnita em fumarolas vulcânicas.

Segundo Gargantini et al. (1974), o sulfato de amônio possui densidade relativa de 1,67 que, normalmente, pode se decompor a 235 ${ }^{\circ} \mathrm{C}$. Além disso, ele é também insolúvel em etanol e muito solúvel em água. Gargantini et al. (1974) afirmam que inicialmente, o $\left(\mathrm{NH}_{4}\right)_{2} \mathrm{SO}_{4}$ foi sintetizado por meio da produção da gás-carvão a partir dos licores de amônia que eram produzidos. Contudo, posteriormente, passou a ser sintetizado por meio de reação direta entre o ácido sulfúrico e gás amoníaco.

De acordo com Carvalho et al. (2010), o sulfato de amônio pode se decompor a partir do aquecimento e, com isso, liberta amônia (hidrogenossulfato de amônia) e, em alguns casos, amoníaco, água e dióxido de enxofre. Como fertilizantes, ele é aplicado na agricultura para repor enxofre e nitrogênio aos solos cultivados.

Gargantini et al. (1974) explicam que, por se tratar de um gás com menor concentração de nitrogênio, possui elevado custo por tonelada de produto. Entretanto, pode facilmente oferecer perdas menores de nitrogênio através de volatilização e lixiviação, sendo estes, dois fenômenos que apresentam variação conforme a umidade do solo.

Em termos de saúde e meio ambiente, Carvalho et al. (2010) enfatiza que o sulfato de amônio não é um sólido inflamável, possui baixa toxidade e não apresenta perigo para seu transporte. Contudo, a água contaminada pelo sulfato de amônio faz com que ela se torne imprópria para ser utilizada para qualquer finalidade. Além disso, apresenta elevada concentração de material em suspensão e isto pode, em alguns casos, provocar irritação no nariz e trato respiratório de uma pessoa. Por isso, é recomendado que não haja contato direto com a pele e olhos, uma vez que pode causar irritação, vermelhidão e coceira.

Como subproduto da coqueificação, o sulfato de amônio aproveitado é constituído ao se encaminhar o gás de coqueria aos 
saturadores. Desta forma, o gás de coqueria é feito borbulhar em ácido sulfúrico, dando origem ao sulfato de amônio.

\subsection{GÁS COMBUSTÍVEL}

Acredita-se que há uma tendência para que as matrizes energéticas a base de petróleo se esgotem e, por isso, o homem tem buscado por novas alternativas de combustíveis confiáveis ou que estabeleçam um melhor aproveitamento energético (GUILHERME e CASTRO, 2012). Segundo estes autores, os gases têm desempenhado função de suma relevância neste cenário. Isto porque, a extração de gás natural de reservas fósseis; o aproveitamento de dejetos para produzir biogás; e as frações de petróleo para compor o Gás Liquefeito de Petróleo (GLP) têm tomado, a cada dia que passa, mais espaço como combustíveis de qualidade, baixo custo e por se mostraram uma alternativa para substituírem os combustíveis líquidos que são produzidos a partir do petróleo.

Diante do exposto, Guilherme e Castro (2012) observam que o gás combustível, da mesma forma que o petróleo, se refere a um combustível fóssil, limitado a reservas que são encontradas apenas no interior da terra.

De acordo com Alves, Melchiades e Boschi (2008), o gás combustível é um hidrocarboneto ou mistura deste que se encontra em estado gasoso quando nas condições atmosféricas normais, sendo ele o resultado da decomposição da matéria orgânica fóssil ocorrida no interior da Terra. Mas, conforme encontrado na natureza, no seu estado bruto, o gás combustível é formado principalmente pelo metano, apresentando em pequenas proporções o butano, etano, hidrocarbonetos mais pesados e propano.

Para Santos et al. (2007), o gás combustível, comumente conhecido como gás natural, geralmente associado ao petróleo, se refere a uma mistura de hidrocarbonetos leves que se mantém no estado gasoso quanto em uma temperatura e pressão atmosféricas ambientes. O gás natural é, portanto, as misturas de hidrocarbonetos gasosos contendo maior quantidade de moléculas de metano $\left(\mathrm{CH}_{4}\right)$. Normalmente, esse tipo de gás é encontrado originalmente no subsolo, podendo ser marinho ou terrestre, em acumulações de rochas porosas.

Conforme os autores, esse tipo de gás pode, inclusive, apresentar na sua composição moléculas mais pesadas do que o $\mathrm{CH}_{4}$, como, por exemplo, o propano. É possível também extrair do petróleo bruto todos os hidrocarbonetos gasosos por meio dos processos do carvão ou de 
refino, ou, ainda, através de sua gaseificação em processos conhecidos por Coal-to-Gas (CTG). Mas, no que se refere ao propano e o butano, especificamente, quando são extraídos na refinaria em gaseificadores de carvão ou unidades de processamento de gás natural, resultam na formação do gás liquefeito do petróleo (GLP).

Além do exposto, o gás natural apresenta uma proporção que pode variar conforme ele é encontrado na natureza. Nesse sentido, Rangel e Buchler (2005) explicam que, por isso, pode acontecer de ser encontrado petróleo com pouquíssimo ou nenhum gás associado, assim como jazidas as quais, existe praticamente somente o gás natural. É importante destacar que o gás no mundo é comumente encontrado não associado ao petróleo.

Corroborando o exposto pelos autores acima, Alves, Melchiades e Boschi (2008) sinalizam que caso haja predominância do petróleo sobre o gás, as condições de exploração da jazida serão determinadas pela produção do petróleo. Por sua vez, o gás natural associado ao petróleo passará a ser tratado como um subproduto deste. Mas, caso não exista condições financeiras necessárias para aproveitar o gás natural, este é, portanto, queimado em queimadores de segurança ou reinjetado na jazida. Entretanto, em casos em que o gás natural é dominante sobre o petróleo, isto é, que seja não associado, o seu aproveitamento econômico se torna a condição fundamental para o desenvolvimento da produção.

Rangel e Buchler (2005) afirmam que, pelo fato de o gás natural ser uma fonte energética não renovável, tem por essa característica própria, a possibilidade de esgotamento. Ainda assim, acredita-se que ele possa ser algum dia, o combustível mais indicado para fazer a substituição do petróleo, considerando os tempos atuais.

Em todo o mundo é reconhecido que a função estratégica do gás natural tem aumentado de forma significativa como fonte de energia, especialmente, devido ao baixo impacto ambiental que provoca quando comparado com outras fontes fósseis. Acredita-se que o uso do gás natural em equipamentos corretos e indicados para sua aplicação tem maior tendência a ser pouco poluente (GUILHERME e CASTRO, 2012).

Guilherme e Castro (2012) ainda afirmam que, quando processados de forma adequada, a combustão de gases combustíveis é quase nula de poluentes como partículas sólidas ou óxidos de enxofre, por exemplo, possibilitando que a população faça uso do gás de maneira direta. 
Dentre as vantagens que podem ser apontadas do gás combustível são, segundo Santos et al. (2007), o fato de o gás permitir que ocorra uma combustão com alto rendimento térmico, assim como regulagem e controle simples da chama. Desta forma, torna-se possível que haja a obtenção de diminuição quanto à amplitude de consumo de energia por parte do comércio, indústria ou mesmo em residências.

Além do exposto, os autores ainda salientam que, ao se permitir o contato direto da chama com os produtos produzidos, ou com os gases de combustão, a aplicação na indústria do gás natural auxilia para o crescimento da qualidade e competitividade de tais produtos. Outra vantagem do gás natural se refere ao fato de ele poder proporcionar benefícios ambientais e econômicos se usado no setor de transporte, ao fazer a substituição do óleo diesel ou da gasolina.

Nesse contexto, Santos et al. (2007) corroboram:

O gás natural pode ser usado como matéria-prima da indústria química, sendo usado na fabricação de produtos com muito maior valor agregado como plásticos e lubrificantes. Mesmo se essa relação entre usos energéticos e nãoenergéticos dos gases não possa ser tratada ao longo deste artigo, é evidente que o conceito de "Civilização do gás" abarca obrigatoriamente ambos os usos (SANTOS et al., 2007, p. 2).

No caso do gás de coqueira, Santos (2010) afirma que ele apresenta uma composição específica, conforme ilustrado na Tabela 3:

Tabela 3 - Composição do gás de coqueria purificado

\begin{tabular}{c|c}
\hline Substância & Composição em volume (\%) \\
\hline $\mathrm{CO}$ & $5,8-6,8$ \\
$\mathrm{CO}_{2}$ & $1,5-2,2$ \\
$\mathrm{CH}_{4}$ & $27,2-29,2$ \\
$\mathrm{C}^{2} \mathrm{H}_{4}$ & $1,3-2,8$ \\
$\mathrm{O}_{2}$ & $0,0-0,4$ \\
$\mathrm{H}_{2}$ & $56,0-57,0$ \\
$\mathrm{~N}_{2}$ & $1,0-4,6$ \\
\hline
\end{tabular}

Fonte: Santos, 2010, p. 26.

Santos (2010) ainda explica que o gás de coqueira deve passar por todo o processo de purificação para que, desta forma, sejam 
condensadas todas as frações de subprodutos. A partir disso, é obtido um gás purificado que poderá ser usado nas demais fases dentro da usina. Depois de ter passado pela purificação, o gás é enviado ao gasômetro.

Entretanto, o autor esclarece que para este gás ser usado nas próprias baterias de coqueificação como combustível e demais áreas da usina ele precisa apresentar determinadas substâncias dentro dos limites mostrados na tabela 4:

Tabela 4 - Limite máximo permitido de algumas substâncias no gás de coqueria

\begin{tabular}{cc}
\hline Substância & Quantidade máxima g/m $\mathbf{m}^{\mathbf{3}}$ (nas CNTP) \\
\hline Alcatrão & 5 \\
Ácido Sulfídrico $\mathrm{H}_{2} \mathrm{~S}$ & $6,0-8,0$ \\
Benzol & $1,0-3,0$ \\
$\mathrm{NH}_{3}$ & 20 \\
$\mathrm{HCN}$ & 1,5 \\
\hline
\end{tabular}

Fonte: Santos, 2010, p. 26.

OBS: CNTP - Condições Normais de Temperatura e Pressão

O autor salienta que é importante manter a densidade e o poder calorífico deste gás purificado os mais constantes possíveis, de modo que se mantenha uma operação regular dos queimadores no momento em que estão sendo usados. Além disso, devem ser diminuídos ao mínimo os teores de alcatrão e naftaleno para prevenir a possibilidade de entupimento nas tubulações que fazem a distribuição.

\subsection{EFLUENTES LÍQUIDOS}

Segundo Navarro e Palladino (2009), comumente, os efluentes líquidos são os despejos originados de estabelecimentos industriais ou de atividades humanas, conhecidos como efluentes industriais e doméstico, lançados no meio ambiente. No que se refere aos efluentes industriais, estes também são gerados por meio da atividade da coqueificação. Quando tais efluentes líquidos são oriundos da coqueificação, geralmente a quantidade de águas residuais geradas se encontra em uma faixa aproximada de 0,08 a $0,38 \mathrm{~m}^{3}$ considerando por tonelada de carvão. Entretanto, tal faixa pode sofrer variação conforme o tipo de processo de tratamento do gás. $\mathrm{O}$ efluente líquido oriundo do processo de coqueificação tem origem a partir de duas etapas que são o 
apagamento do coque incandescente e lavagem e a outra é o resfriamento do gás das baterias de coqueificação (NAVARRO e PALLADINO, 2009).

Calfa e Torem (2007) explicam que o coque incandescente, depois de passar pela etapa de desenfornamento deve ser encaminhado até a estação de apagamento. Para que ele possa, então, ser resfriado, é usada uma grande quantidade de água que, por conseguinte, gera um efluente líquido composto por altas concentrações de sólidos em suspensão por causa dos finos de coque. Essa etapa da coqueificação dá origem aos efluentes líquidos, ainda que pequeno, pois, a maior parte da água usada se evapora e gira em 0,0 a $0,5 \mathrm{~m}^{3}$ por cada tonelada de coque incandescente.

Sobre o resfriamento, Santos (2010) enfatiza que o gás proveniente das baterias de coqueificação dão origem a um efluente semelhante à forma de licor amoniacal, contendo fenol, altas concentrações de amônia, cianetos e demais substâncias tóxicas. Neste caso, o autor ilustra na Tabela 5 as faixas aproximadas de concentração dos contaminantes encontrados nos efluentes da coqueria.

Tabela 5 - Concentrações e $\mathrm{pH}$ de contaminantes nos efluentes da coqueria

\begin{tabular}{ll}
\hline \multicolumn{1}{c}{ Contaminante/pH } & \multicolumn{1}{c}{ Faixa } \\
\hline $\mathrm{pH}$ & 8,5 a 9,5 \\
Tiocianato & 50 a $100 \mathrm{mg} / \mathrm{L}$ \\
Tiossulfato & 110 a $220 \mathrm{mg} / \mathrm{L}$ \\
Amônia Total & 800 a $1400 \mathrm{mg} / \mathrm{L}$ \\
Sulfeto & 10 a $20 \mathrm{mg} / \mathrm{L}$ \\
Cianeto & 10 a $50 \mathrm{mg} / \mathrm{L}$ \\
Fenol & 500 a $1000 \mathrm{mg} / \mathrm{L}$ \\
Cloreto & 4000 a $4200 \mathrm{mg} / \mathrm{L}$
\end{tabular}

Fonte: Santos, 2010, p. 27.

Segundo Mariano et al. (2010), os efluentes líquidos provenientes da etapa de lavagem e resfriamento do gás possuem concentração de determinados poluentes convencionais, como, por exemplo, cianeto, Sólidos Dissolvidos Totais (SDT), fenol, Sólidos Suspensos Totais (SST), amônia, Demanda Bioquímica de Oxigênio (DBO), óleos e 
graxas. Mas, na etapa do apagamento do coque, as concentrações dos poluentes encontrados e em grande quantidade são SST e Demanda Química de Oxigênio (DQO), por causa de haver os finos de coque.

A respeito dos efluentes da lavagem e resfriamento do gás e do apagamento do coque, Santos (2010) especifica na Tabela 6.

Tabela 6 - Efluentes da lavagem e resfriamento do gás e do apagamento do coque

\begin{tabular}{|c|c|c|c|}
\hline Parâmetro & $\begin{array}{c}\text { Concentração } \\
\text { Lavagem e } \\
\text { resfriamento dos } \\
\text { gases }\end{array}$ & Apagamento & $\begin{array}{c}\text { Limite para } \\
\text { descarte de } \\
\text { efluente } \\
\text { (resolução } \\
\text { CONAMA 357) }\end{array}$ \\
\hline $\mathrm{pH}$ & 7,6 & 7,5 & 5,0 a 9,0 \\
\hline SDT(PPM) & 3236 & 991 & - \\
\hline SST (PPM) & 1242,5 & 1582 & - \\
\hline $\mathrm{OD}(\mathrm{MG} / \mathrm{L})$ & - & 5,7 & - \\
\hline DQO (MG/L) & 2713,2 & 8856 & - \\
\hline DBO9mg/L) & 3,8 & 0,9 & - \\
\hline Fenol(MG/L) & 0,6 & 0,2 & 0,5 \\
\hline Amônia (MG/L) & 22,4 & 9,24 & 20 \\
\hline Cianeto $(\mathrm{mg} / \mathrm{L})$ & 10 & - & 0,2 \\
\hline $\begin{array}{l}\text { Óleos e Graxas } \\
(\mathrm{mg} / \mathrm{L})\end{array}$ & 758,4 & 22,4 & 20 \\
\hline
\end{tabular}

Fonte: Santos, 2010, p. 28.

Sobre os finos de coque, Santos et al. (2010) enfatizam que eles podem ser retirados por meio de sedimentação, em que se direciona o efluente para um tanque de decantação e se torna possível, também, recuperar os finos de coque. Além disso, a água poderá ser reaproveitada para outras finalidades. Quanto aos fenóis, os autores afirmam que este também podem ser recuperados por meio da extração por solventes orgânicos, tais como benzeno, metil isobutil cetona, acetato de butila e éter di-isopropílico. Esses são solventes que precisam possuir determinadas características que são o elevado valor da constante de equilíbrio Kp para fenóis, ponto de ebulição menor que a do fenol, ser pouco solúvel na água e ter boa estabilidade térmica e química.

Ao se usar soluções de cloreto de ferro ou sulfato de ferro, é possível precipitar e remover os cianetos em forma de complexos. Tais complexos que são constituídos devido à interação do cianeto com o sulfato de ferro e o cloreto de ferro têm um considerável valor comercial 
(NAVARRO e PALLADINO, 2009). Ambas as soluções, ou seja, a de cloreto de ferro e as de sulfato de ferro, normalmente agem como coagulantes, contribuindo na remoção de graxas, sólidos em suspensão e óleos. Destaca-se, contudo, que os finos de coque têm a remoção mais eficiente por meio do cloreto de ferro, chegando a atingir em média $88 \%$ de cianeto removido. Quanto à remoção por precipitação pelo sulfato de ferro pode atingir aproximadamente $86 \%$ de remoção, pois, a água de lavagem neste caso não se mostra suficiente para se chegar ao limite necessário para descarte (NAVARRO e PALLADINO, 2009).

Segundo Santos (2010), no caso da amônia, quando em basicidade $(\mathrm{Kpb})$ de 4,7 pode ser removida por meio da destilação a vapor ou com a aplicação de uma técnica que faz a troca iônica. Se for feita sua remoção por meio da destilação a vapor, a amônia tem o seu $\mathrm{pH}$ do licor amoniacal aumentado para valores superiores a 11,0 e o vapor é colocado em uma temperatura de $93^{\circ}$ ou maior. Trata-se de um processo em que se pode fazer a destilação da amônia com grande eficiência. Quanto à técnica de troca iônica, esta pode ser realizada por meio de zeólitas sintéticas que, por sua vez, se referem a um grupo de minerais com estrutura porosa. A troca iônica pode ser regenerada depois da sua saturação, em salmoura.

\subsection{EFLUENTES GASOSOS}

A emissão de efluentes gasosos provenientes do processo de uma coqueificação são diversos. Nesse contexto, Afonso e Pereira (2010) salientam que na coqueria, em todas as etapas, são de grande intensidade as emissões atmosféricas, seja no processo de manuseio do carvão, no carregamento, na combustão, no descarregamento do coque incandescente e no apagamento do coque e purificação do gás de exaustão. Deve-se considerar ainda, uma grande parcela de emissões que ocorrem nos vazamentos das câmaras de combustão.

De acordo com Pereira Neto et al. (2008), a etapa de manuseio do carvão é constituída pelo descarregamento do coque incandescente, armazenagem, transporte interno, preparação, carregamento na torre de carvão e no carro. Depois de passar pela purificação com ciclones, o material particulado emitido pode chegar a 55 gramas por tonelada de carvão.

As emissões, segundo Santos (2010), geralmente acontecem nas portas e entradas de carregamento e, como consequencia destes vazamentos, surgem também algumas emissões por tonelada de coque produzido. Tais emissões são de 0,7 a $7 \mathrm{~g}$ de material particulado; 3 a 
$39 \mathrm{~g}$ de $\mathrm{CO} ; 0,18$ a $1,8 \mathrm{~g}$ de $\mathrm{NH}_{3 ;} 0,3$ a $2,4 \mathrm{~g}$ de $\mathrm{CO}_{2}$; 0,036 a $0,9 \mathrm{~g}$ de $\mathrm{H}_{2} \mathrm{~S}$; $1 \mathrm{a} 23 \mathrm{~g}$ de benzeno; e 0,06 a $0,6 \mathrm{~g}$ de $\mathrm{NO}_{\mathrm{x}}$.

Afonso e Pereira (2010) salientam que durante o processo de combustão o próprio gás de coqueria e o gás de alto forno são usados como fonte de energia térmica, depois de ter passado por um intenso processo de purificação nas plantas de recuperação de subprodutos. Além disso, durante o processo de coqueificação, nota-se maior relevância nas emissões de $\mathrm{NO}_{\mathrm{x}}$ e $\mathrm{SO}_{2}$. $\mathrm{O}$ dióxido de enxofre, por exemplo, se apresenta com níveis entre 80 e $300 \mathrm{~g}$ por tonelada de coque produzido, para este mesmo gás dessulfurizado, caso tenha sido usado um gás de coqueria dessulfurizado com uma faixa aproximada entre $240 \mathrm{~g}$ e $1800 \mathrm{~g}$ de $\mathrm{NO}_{\mathrm{x}}$ por tonelada de coque produzido.

Conforme Santos (2010), quando pronta, a etapa de desenfornamento de coque possui fatores de emissão superiores a $210 \mathrm{~g}$ de poeira por tonelada de coque produzido; de $\mathrm{CO}$ são 6 a $36 \mathrm{~g}$; de $\mathrm{SO}_{2}$ entre 6 e 24g. Na etapa de apagamento úmido do coque incandescente, são emitidos por tonelada de coque produzido $140 \mathrm{~g}$ de material particulado; 1 a 100mg de hidrocarbonetos aromáticos; 51 a $81 \mathrm{~g} \mathrm{de} \mathrm{H}_{2} \mathrm{~S}$; 300 a $1410 \mathrm{~g}$ de $\mathrm{CO} ; 4,5 \mathrm{~g}$ de $\mathrm{NH}_{3}$.

Segundo Weber, Cybis e Beal (2010), nos casos em que não exista medidas de controle de emissões no apagamento a úmido, normalmente a taxa de emissão de material particulado atinge a níveis aproximados entre 200 a $400 \mathrm{~g}$ por tonelada de coque.

A respeito dos sistemas de apagamento a seco do coque, Santos (2010) explica que eles são munidos de filtros de manga e ciclone, apresentando eficiência superior a $98 \%$ e diminui as emissões de material particulado para $10 \mathrm{~g}$ por tonelada de coque produzido, em média. Segundo o autor, é importante destacar que este tipo de apagamento também se mostra viável em termos ambientais, pois, por meio dele, não são gerados efluentes líquidos.

Sobre a etapa de purificação, Santos (2010) afirma ser constituída por uma diversidade de fases de limpeza do gás de exaustão de modo a se adquirir subprodutos, como, por exemplo, o gás de coqueria. Trata-se de uma etapa com emissões de hidrocarbonetos aromáticos que variam entre 1,5 a $4,5 \mathrm{mg}$ e $0,1 \mathrm{~g}$ de benzeno por tonelada de coque produzido.

Bortoli et al. (2012) observa que, com a emissão de efluentes gasosos são liberadas várias substâncias, sendo que, algumas delas se apresentam com grande risco à saúde humana e ao meio ambiente. Tais substâncias com elevado risco ao meio ambiente e à saúde humana são o dióxido de enxofre $\left(\mathrm{SO}_{2}\right)$; o $\mathrm{NO}_{\mathrm{x}}$ que pode incluir $\mathrm{NO}, \mathrm{NO}_{2}, \mathrm{~N}_{2} \mathrm{O}_{5}, \mathrm{NO}_{3}$, dentre outros; e o $\mathrm{H}_{2} \mathrm{~S}$. 
Para Santos (2010), são impostas por lei o limite para a emissão de tais gases, exatamente por serem prejudiciais ao meio ambiente e ao homem, pela resolução Conama $\mathrm{n}^{\circ} 382$ de 2006, conforme apresentados na Tabela 7.

Tabela 7 - Limites máximos de emissões de poluentes atmosférico para coqueria

\begin{tabular}{clcccc}
\hline $\begin{array}{c}\text { Unidade de } \\
\text { produção }\end{array}$ & $\begin{array}{c}\text { Fontes de } \\
\text { emissão pontual }\end{array}$ & $\mathrm{MP}(1)$ & $\mathrm{SO}_{2}(1)$ & $\begin{array}{c}\mathrm{NO}_{\mathrm{x}}(1) \\
\left(\mathrm{como}^{\mathrm{N}}\right. \\
\left.\mathrm{NO}_{2}\right)\end{array}$ & $\% \mathrm{O}_{2}(1)$ \\
\hline Coqueira & $\begin{array}{l}\text { Sistema de } \\
\text { despoeiramento } \\
\text { do } \\
\text { desenformamento }\end{array}$ & 40 & N.A & N.A & N.A \\
$\begin{array}{l}\text { Câmara de } \\
\text { combustão dos } \\
\text { fornos de coque }\end{array}$ & 50 & 800 & 700 & $7,00 \%$ \\
\hline
\end{tabular}

Fonte: Resolução CONAMA 382 de 2006. 


\section{METODOLOGIA}

A metodologia de pesquisa adotada foi o estudo de caso na Empresa Alfa, situada na região de Timóteo, com o objetivo de realizar a comparação da viabilidade econômica na substituição do coque pelo gás natural e o carvão vegetal utilizado no Alto Forno 2 da supracitada empresa. A estratégia adotada foi a de uma pesquisa quantitativa exploratória, onde foram avaliadas as quantidades consumidas destas matérias-primas para produção de 1 tonelada de ferro gusa. O mesmo estudo de caso também foi adotado para realizar a comparação da viabilidade ambiental dos mesmos.

Com base no estudo de caso realizado, tornou-se possível utilizar a pesquisa qualitativa cujo objeto é uma unidade que se analisa profundamente, caracterizado como um estudo de uma entidade, um programa, uma instituição, um sistema, uma pessoa ou uma unidade social.

\subsection{PROCEDIMENTOS METODOLÓGICOS}

Para a pesquisa, informações como o custo de aquisição do coque, aquisição de novos equipamentos, mão de obra, custo operacional e porcentagem foram avaliados e organizados em planilhas eletrônicas do Microsoft Excel®, utilizado como ferramenta na realização dos cálculos. A amostra foi composta por informações obtidas na Empresa Alfa durante o ano de 2014.

Para a análise da viabilidade econômica, foi aplicado o Valor Presente Líquido (VPL). O critério do valor presente líquido (VPL) fornece indicação a respeito do potencial de criação de valor de um investimento. Se o valor presente líquido for maior do que zero, por exemplo, significa que o investimento fornece um valor adicional ao investidor após devolver o capital empregado e remunerar todos os agentes financiadores do investimento (BRASIL, 2004).

Portanto, em termos gerais, o VPL maior do que zero significa valor extra para o investidor e assim, o projeto poderá ser aceito. Agora, caso o VPL seja menor que zero, significa que o investidor deverá perder valor com o investimento.

Nota-se que o valor presente líquido é a fórmula matemáticofinanceira de se determinar o valor presente de pagamentos futuros descontados a uma taxa de juros apropriada, menos o custo do investimento inicial. 
Considerado um método exato, o VPL tem como princípio o valor do dinheiro no tempo através de análises de fluxos de caixa, trazendo para o presente os valores de um dado fluxo de caixa. Diante disso, Ross, Westerfield, Jaffe (2002, p. 68) salienta que "O valor presente líquido de um investimento é o valor presente dos fluxos futuros de caixa desse investimento, menos o custo inicial do investimento"

Para melhor esclarecimento, a expressão algébrica do Valor Presente Líquido é representada da seguinte forma:

$$
V P L=-C_{0}+\sum_{i=1}^{T} \frac{C i}{(1+r)^{i}}
$$

Onde:

$\mathrm{C}_{0}=$ Investimento inicial

$\mathrm{Ci}=$ Fluxo de caixa previsto para a data i onde i é o índice

$\mathrm{r}=$ Taxa de juros apropriados

$\mathrm{i}=$ Período correspondente ao fluxo de caixa nessa data

$\mathrm{T}=$ Prazo total do investimento.

Utilizado nas tomadas de decisões, o VPL é analisado da seguinte forma:

- Se o VPL for positivo;

- Se o VPL for igual à zero, significa que os valores referentes às entradas são iguais aos das saídas. Nesse caso, devem-se analisar os riscos que envolvem o projeto;

- Se o VPL for negativo, o projeto deverá ser rejeitado, uma vez que o investimento não é economicamente atrativo porque os valores da entrada de caixa são menores do que o valor presente da saída de caixa.

Estas alternativas referem-se apenas a critérios de decisões no uso do valor presente líquido. Dessa forma, no caso de vários projetos, cada um deve ser analisado minuciosamente, e o que obtiver maior VPL deve ser aprovado. 
Como método de análise ambiental, utilizou-se como ferramenta a Matriz de Leopold. A referida matriz leva em consideração cada atividade e o potencial que apresenta para causar impacto ao meio ambiente. A matriz é formada por duas listas, sendo uma lista constituída por 100 ações humanas que podem provocar impactos ambientais e a outra possui 88 elementos ambientais que podem ser prejudicadas pelas ações humanas. Para estudos de impactos ambientais, a Matriz de Leopold tem sido a mais adotada, pois procura relacionar os impactos de determinada ação humana causada por determinado empreendimento com várias peculiaridades ambientais de sua área de influência.

$\mathrm{Na}$ tabela proposta, os scores usados servem para indicar os impactos através do tipo e meio afetado de cada produto em relação às substâncias emitidas, permitindo a avaliação dos impactos causados aos meios físico, biótico e antrópico, conforme segue exemplificado no Quadro 1. Além disso, permite ainda avaliar tais impactos quanto aos seguintes atributos: magnitude e importância.

Na Matriz de Leopold, para cada produto, são identificadas e avaliadas as características de um componente de determinado meio (físico, biótico e antrópico), e os possíveis tipos de impactos que poderão ocorrer, facilitando na identificação de cada característica e o meio afetado pela emissão de determinado produto, tendo-se, ao mesmo tempo, uma avaliação do impacto em termos de magnitude $\mathrm{e}$ importância, como segue no Quadro 1. 
QUADRO 1 - Exemplo dos Parâmetros de Avaliação Utilizados na Matriz de Impactos:

\begin{tabular}{|c|c|c|}
\hline \multicolumn{3}{|c|}{ Parâmetros de Avaliação Utilizados na Matriz de Impactos } \\
\hline ATRIBUTO & $\begin{array}{l}\text { SIGNIFICADO DO PARÂMETRO } \\
\text { DE AVALIAÇÃO }\end{array}$ & SÍMBOLO \\
\hline \multirow{3}{*}{$\begin{array}{l}\text { MAGNITUDE } \\
\text { Exprime } \\
\text { extensão } \\
\text { impacto, através de } \\
\text { uma valoração } \\
\text { gradual que se dá } \\
\text { ao mesmo, a partir } \\
\text { de } \\
\text { determinada ução } \\
\text { do projeto. }\end{array}$} & $\begin{array}{l}\text { PEQUENA - De magnitude } \\
\text { inexpressiva, inalterando a característica } \\
\text { ambiental considerada. }\end{array}$ & $\mathbf{P}$ \\
\hline & $\begin{array}{l}\text { MÉDIA - De magnitude expressiva, } \\
\text { porém sem alcance para descaracterizar } \\
\text { a característica ambiental considerada. }\end{array}$ & $\mathbf{M}$ \\
\hline & $\begin{array}{l}\text { GRANDE - De magnitude tal que possa } \\
\text { levar à descaracterização da } \\
\text { característica ambiental considerada. }\end{array}$ & G \\
\hline \multirow{3}{*}{\begin{tabular}{|lr}
\multicolumn{2}{|l}{ IMPORTÂNCIA } \\
$-\quad$ Indica & a \\
importânicia & ou \\
significância & do \\
impacto & em \\
relação à & sua \\
interferência & no \\
meio. &
\end{tabular}} & 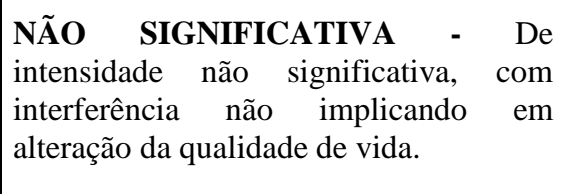 & 1 \\
\hline & $\begin{array}{l}\text { MODERADA } \\
\text { interferência }- \text { Intensidade da } \\
\text { recuperáveis, quando adversa, ou } \\
\text { refletindo na melhoria da qualidade de } \\
\text { vida, quando benéfica. }\end{array}$ & 2 \\
\hline & $\begin{array}{l}\text { SIGNIFICATIVA - Intensidade da } \\
\text { interferência acarreta perda da qualidade } \\
\text { de vida, quando adversa, ou ganho, } \\
\text { quando benéfica. }\end{array}$ & 3 \\
\hline
\end{tabular}

Fonte: Elaborado pelo autor.

De acordo com Moreira (1993), ao descrever na Matriz os impactos de cada ação de determinado empreendimento, torna-se mais fácil realizar a identificação de cada característica e quais os meios afetados, obtendo, ainda, uma avaliação desse impacto quanto à sua relevância, tipo, duração e magnitude. Neste caso, são identificados e posteriormente avaliados, para cada tipo de projeto e para cada 
característica de um elemento que constitui determinado meio (abiótico, biótico e antrópico), os impactos que possivelmente poderão ocorrer e, desta forma, fazer uma descrição desse impacto na própria Matriz.

Conforme Guerra e Carvalho (1995), a referida Matriz pode ser interpretada de acordo com o seu princípio básico, ou seja, apontar todas as interações possíveis que possa haver entre os fatores e as ações e, depois, estabelecer tais interações em uma escala de 1 a 10 quanto à importância e magnitude de cada impacto, de modo a identificar se este é positivo ou negativo.

Além disso, sua interpretação consiste em considerar a valoração da magnitude é relativamente empírica ou objetiva, isto porque se refere ao nível de modificação causado em decorrência da ação sobre o fato ambiental. Desta forma, entende-se que a pontuação dada à importância é, portanto, normativa ou subjetiva, pois envolve fatores como peso relativo ao afetado no âmbito do projeto. $\mathrm{O}$ estabelecimento de tais pesos forma um dos mais críticos pontos da Matriz, não apenas quanto às técnicas matriciais, mas quanto aos outros métodos quantitativos.

Para Silva, Moraes e Machado (2015), a interpretação dada à Matriz de Leopold pode ser voltada para a análise dos fatores considerados criticáveis, ou seja, aqueles que não podem ser identificados, nem analogamente às check-lists para se manter uma inter-relação entre os impactos. Tal fato permite refletir sobre uma possível dupla contagem e a pouca ênfase atribuída aos fatores culturais e sociais.

Os autores ainda enfatizam sobre a utilização dessa Matriz e sua pertinência ou não no que se refere ao cálculo de um índice global de impacto ambiental consequente da soma ponderada, ou seja: magnitude $\mathrm{x}$ importância de determinados impactos. Considerando a diferente natureza que cada impacto pode apresentar, a não contabilização de índice global ainda é muito discutida.

No trabalho em questão, as emissões da coqueificação foram verificadas a partir de cada substância que foi diferenciada por meio de letra minúscula e, por conseguinte, apresentada a Matriz de Leopold com a indicação da magnitude e importância dos impactos gerados por cada substância emitida. 


\section{RESULTADOS E DISCUSSÃO}

O combustível é um produto consumido em grande escala em todo o mundo causando impactos ambientais e elevados custos para a sua produção. Nesse contexto, Costa (2002) enfatizou que grande parte das indústrias siderúrgicas tem buscado métodos de sistemas de gestão ambiental eficazes para atenderem a questão ambiental de forma correta.

Considerando o fato de que o consumo de combustível é alto é demonstrada na Tabela 8 a produtividade e consumo de combustível com base nos altos fornos 1 e 2 .

Tabela 8 - Produtividade e consumo de combustível

\begin{tabular}{ccc}
\hline Dados & $\begin{array}{c}\text { Alto forno1 } \\
\text { (carvão vegetal) }\end{array}$ & Alto forno2 (coque) \\
\hline $\begin{array}{c}\text { Produção de gusa (toneladas) } \\
\text { Consumo de combustível } \\
\text { (toneladas) }\end{array}$ & 185000 & 377600 \\
\hline
\end{tabular}

Fonte: Dados da pesquisa.

\subsection{COMPARAÇÃO DA VIABILIDADE ECONÔMICA}

\subsubsection{Comparação da viabilidade econômica entre o gás natural e o coque}

O gás natural foi definido na literatura, segundo Martinez (2009), como um combustível fóssil encontrado nos reservatórios subterrâneos que pode ou não estar associado ao petróleo. É, na verdade, uma mistura gasosa de hidrocarbonetos saturados, constituído por butano, etano, nitrogênio, propano, dióxido de carbono, pentano e metano, cada qual com determinada quantidade específica.

Além disso, o gás natural é um produto usado comumente, tal como, por exemplo, como combustível e, conforme ilustrado na Tabela 9, pode-se observar o seu custo correspondente para cada $1000 \mathrm{~m}^{3} \mathrm{em}$ cada estado brasileiro e a média nacional: 
Tabela 9 - Custo da produção do gás natural por estado

\begin{tabular}{lc}
\hline ESTADO & TARIFA MÉDIA US\$/1OOOM \\
\hline Paraná & 19,32 \\
RS & 19,21 \\
São Paulo & 17,8 \\
Ceará & 17,73 \\
Pernambuco & 17,68 \\
Alagoas & 17,56 \\
Santa Catarina & 17,15 \\
Paraíba & 17,11 \\
Sergipe & 16,8 \\
Minas Gerais & 16,48 \\
Rio de Janeiro & 16,4 \\
Mato Grosso do Sul & 16,35 \\
Bahia & 15,75 \\
Espírito Santo & 15,14 \\
Rio Grande do Norte & 14,02 \\
\hline
\end{tabular}

Fonte: Elaborado pelo autor da pesquisa.

Conforme se pode constatar na Tabela 9 apresentada, o preço do gás em Minas Gerais é U\$ 16,48,00 ou $\mathrm{R} \$ 44,50$ para cada $1000 \mathrm{~m}^{3}$ de gás natural. Assim sendo, para se produzir 1 tonelada de ferro gusa é necessário aproximadamente $600 \mathrm{~m}^{3}$ de gás natural, logo, o gasto de gás natural para se produzir 1 tonelada de ferro gusa é de $\mathrm{R} \$ 26,70$. Já o custo para se produzir 1 tonelada de coque no setor siderúrgico é de U\$ 100,00 dólares.

Para produzir $1000 \mathrm{~kg}$ de gusa é necessário $458 \mathrm{~kg}$ ou 0,458 toneladas de coque, tem-se que o gasto de coque para se produzir 1000 $\mathrm{kg}$ de gusa é de U\$ 45,80 ou $\mathrm{R} \$ \mathrm{R} \$ 123,70$.

Ao avaliar em termos econômico-ambiental a substituição do coque utilizado em alto-forno, foi possível verificar que economicamente, a utilização do gás natural se mostra mais viável em comparação ao coque, conforme segue, por meio do custo de utilização, conforme ilustrado na Figura 6. 
Figura 6 - Custo de utilização

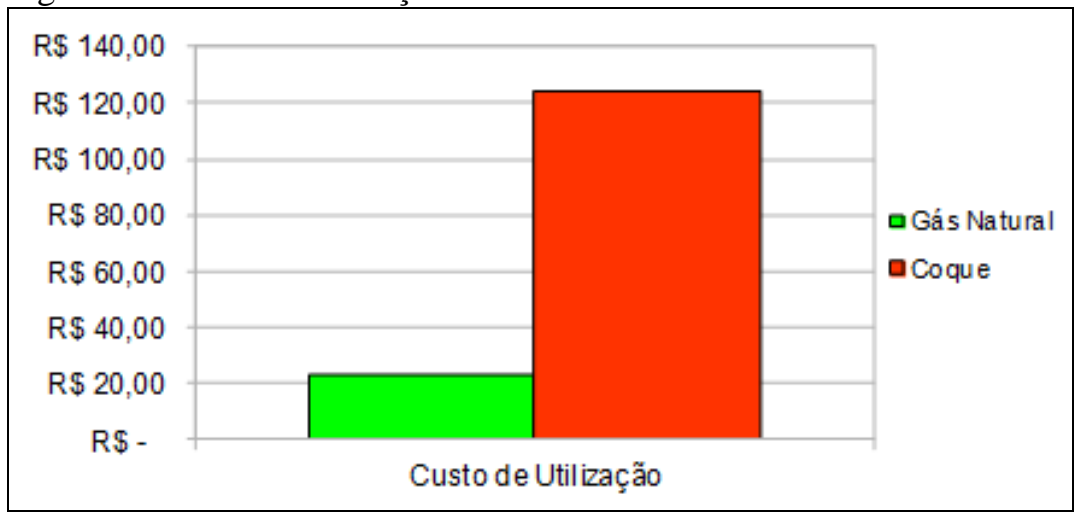

Fonte: Elaborado pelo autor.

\subsubsection{Comparação da viabilidade econômica entre o carvão vegetal e o coque}

O carvão vegetal é uma matéria prima usada em usinas integradas para a produção de tubos de ferro fundido e aço. Conforme Barcellos (2002), no caso das usinas não integradas, esta são responsáveis por produzir em média $16 \%$ de tubos de ferro fundido e aço no território nacional. Comumente, as usinas para a produção de gusa produzem unicamente o ferro-gusa para fornecimento à aciaria e fundições, tendo, como insumo principal, o carvão vegetal.

A Tabela 10 ilustra o custo de produção da tonelada de carvão vegetal por seguimentos. 
Tabela 10 - Custo da produção da tonelada de carvão vegetal por seguimento financeiro

\begin{tabular}{lccc}
\hline \multirow{1}{*}{ Item } & $\begin{array}{c}\text { Empresas } \\
\text { capitalistas }\end{array}$ & $\begin{array}{c}\text { Grandes e médios } \\
\text { produtores }\end{array}$ & $\begin{array}{c}\text { Pequenos } \\
\text { produtores }\end{array}$ \\
\cline { 2 - 4 } & & $(\mathrm{R} \$ / \mathrm{t})$ & \\
Implantação & 46,00 & 46,10 & 26,65 \\
Manutenção & 12,50 & 12,50 & 10,00 \\
Colheita & 82,50 & 31,75 & 31,75 \\
Transporte & 40,00 & 25,00 & 12,50 \\
Carbonização & 68,58 & 26,63 & 35,28 \\
Expedição e frete & 90,00 & 144,00 & 144,00 \\
Impostos (9,67\%) & 41,30 & 34,78 & 31,64 \\
$\quad$ Outros (10\%) & 42,21 & 35,64 & 32,42 \\
$\quad$ Total & 423,09 & 356,40 & 324,24 \\
\hline
\end{tabular}

Fonte: Elaborado pelo autor.

Como a produção de $1000 \mathrm{~kg}$ de ferro gusa no alto forno 1 exige uma massa de 0,418 toneladas de carvão vegetal, tem-se um custo de utilização do carvão vegetal que vai de $\mathrm{R} \$ 135,50$ a $\mathrm{R}$ \$ 176,85.

Novamente, como já mencionado anteriormente, para se produzir $1000 \mathrm{~kg}$ de ferro gusa utilizando-se coque gasta-se $\mathrm{R} \$ 123,70$.

Economicamente, pode-se constatar que o carvão vegetal se mostra inviável em relação ao coque, conforme segue na Figura 7.

Figura 7 - Custo de utilização

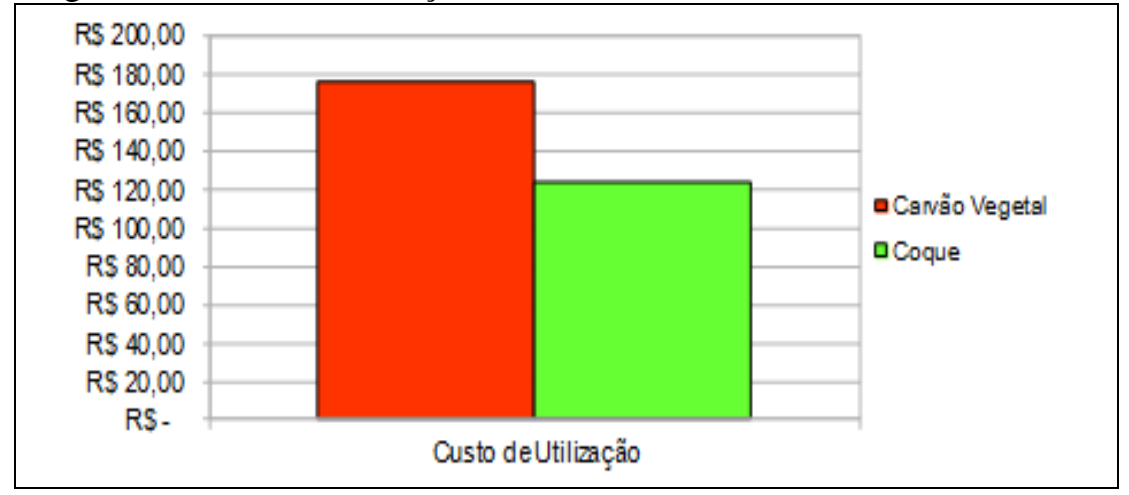

Fonte: Elaborado pelo autor. 
A respeito do coque, Carpío, Silva e Jorge (2003) enfatizam que se trata de um material carbonáceo sólido obtido por meio da destilação do carvão mineral em altos fornos. Mas, para tanto, determinados critérios precisam ser seguidos, como ausência de ar, baixo teor de enxofre, calcular o tempo certo e ter baixo teor de cinzas.

\subsection{COMPARAÇÃO DA VIABILIDADE AMBIENTAL}

\subsubsection{Comparação da viabilidade ambiental entre o gás natural e o coque}

O gás natural e o coque podem, em maior ou menor escala, possuir alguma característica que possa prejudicar ou não o meio ambiente, tornando necessária a análise de ambas quanto à viabilidade ambiental. Nesse contexto, conforme apontado na literatura, Rangel e Buchler (2005) enfatizaram que o gás natural é uma fonte energética não renovável, passível de esgotamento e, somado a essas peculiaridades, Guilherme e Castro (2012) afirmaram que se trata de uma matéria prima que apresenta baixo impacto ambiental e, por isso, tem maior tendência em substituir o combustível por ser pouco poluente.

Além do exposto, o gás natural não gera emissões em processos de beneficiamento, pois, não passa por um processo de produção como os outros combustíveis aqui mencionados.

Por outro lado, Carneiro (2012) explica que o coque, para a sua obtenção, requer a emissão de produtos extremamente nocivos ao meio ambiente e à saúde do homem, tais como amônia, sulfetos, monóxido de carbono, dióxido de carbono e cianetos de hidrogênios. Ainda há efluentes líquidos, como a água contaminada. Tais dados podem ser melhor evidenciados na Tabela 11 que mostra os produtos e emissões da coqueificação. 
Tabela 11 - Produtos e Emissões da Coqueificação

\begin{tabular}{cc}
\hline PRODUTO & MASSA (KG) PARA 1000 KG DE CARVÃO \\
\hline Coque & 624 \\
Alcatrão & 29,5 \\
$\mathrm{CO}$ & 22 \\
$\mathrm{CO} 2$ & 3,9 \\
$\mathrm{CH} 4$ & 87 \\
$\mathrm{C} 2 \mathrm{H} 4$ & 4,6 \\
$\mathrm{O} 2$ & 0 \\
$\mathrm{H} 2$ & 182 \\
$\mathrm{~N} 2$ & 4 \\
$\mathrm{H} 2 \mathrm{~S}$ & 1,2 \\
$\mathrm{NH} 3$ & 1,5 \\
HCN & 2,67 \\
Benzol & 21,3 \\
Óleos leves & 10,01 \\
S. de amônio & 11,23 \\
\hline
\end{tabular}

Fonte: Elaborado pelo autor.

Nota-se que o coque possui uma diversidade de gases poluentes que causa prejuízo ao meio ambiente, diferente do gás natural que, por sua vez, é quase que totalmente isento de enxofre, fazendo com que ocorra maior durabilidade às máquinas e instalações por causar menor corrosão. Além disso, a queima do gás natural não emite particulados como nitretos, cinzas, anidridos ou outros que possam gerar deletérias chuvas ácidas. Com base nisso, entende-se que o gás natural apresenta baixo impacto ambiental e é um combustível ecológico, uma vez que sua queima também produz uma combustão limpa.

Com base no exposto e devido à grande quantidade de emissões poluentes do coque, acredita-se que o gás natural é um produto totalmente isento destas.

\subsubsection{Comparação da viabilidade ambiental entre o carvão vegetal e o coque}

Ainda que determinadas matérias-primas apresentem características favoráveis economicamente ou ambientalmente, quando se pensa em uma substituição é importante realizar dados comparativos. Nesse sentido, ao se buscar conhecer a viabilidade ambiental entre o 
carvão vegetal e o coque, Rosa (2010) afirmou na literatura que no caso do carvão vegetal, sua produção é preocupante ambientalmente, uma vez que é originado da madeira. O Brasil ainda não é um país que seja capaz de atender à demanda dessa matéria prima somente com as florestas plantadas (esta é a maneira mais indicada ambientalmente).

Inicialmente, o carvão vegetal era obtido a partir da madeira proveniente de desmatamento, causando sérios impactos ambientais. Destaca-se, ainda, segundo Rosa (2010), que outro fator problemático em termos ambientais está voltado para a tecnologia que é usada no seu processo produtivo. Isto porque, geralmente, as unidades produtivas do carvão vegetal se localizam perto das florestas que, através do processo de carbonização da lenha proveniente de fornos de alvenaria, lança gases poluentes na atmosfera.

Entende-se, com base no exposto, que o processo de beneficiamento do carvão vegetal gera também uma expressiva quantidade de poluentes além do produto que é o próprio carvão, conforme especificado na Tabela 12.

Tabela 12 - Produtos e emissões do beneficiamento do carvão vegetal

PRODUTOS E EMISSÕES DA MASSA EM KG POR TONELADA CARBONIZAÇÃO

Carvão DE LENHA (BASE SECA)

Ácido Pirolenhoso 299

Ácido Acético 355

Metanol 50

Alcatrão Solúvel 20

Água E Outros 67

Alcatrão Insolúvel

Gases Não Condensáveis 69

$\mathrm{H} 2 \quad 0,63 \%$

$\mathrm{CO} 34 \%$

1,4

$\mathrm{CO}_{2} 62 \%$

76

CH4 2,43\%

134

Etano 0,13\%

Outros $0,81 \%$

0,5

Fonte: Elaborado pelo autor.

É possível também verificar na Figura 8 a quantidade das emissões de produtos gasosos como $\mathrm{CO}, \mathrm{CO}_{2}, \mathrm{CH}_{4}$ e $\mathrm{C}_{2} \mathrm{H}_{4}$. 
Figura 8 - Massa de gás em kg por tonelada de lenha beneficiada

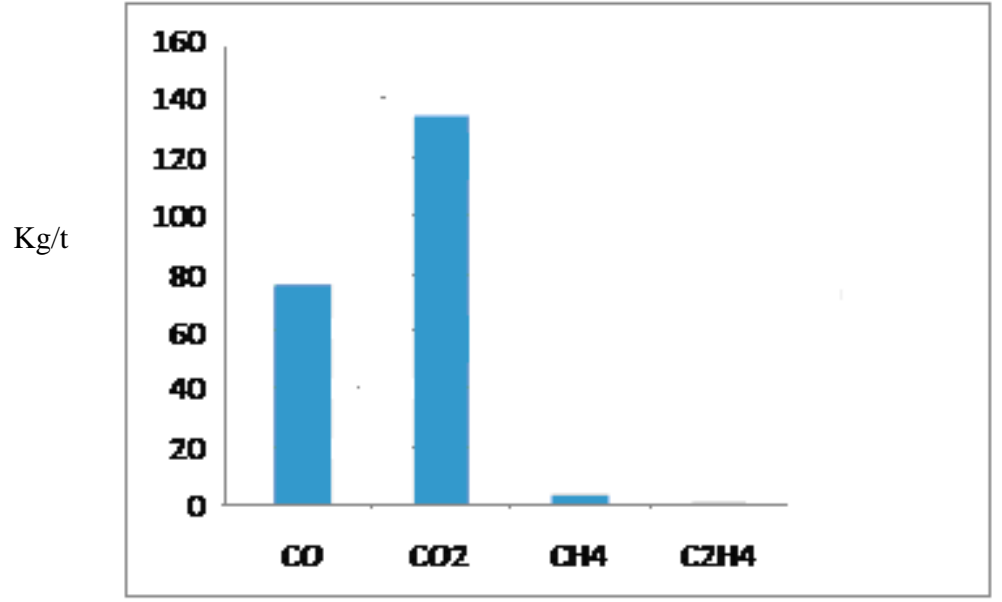

Fonte: Elaborado pelo autor

Buscou-se também verificar na Empresa Alfa, situada na região de Timóteo, quais as emissões de gases referentes à produção do coque. Contudo, deve-se enfatizar que, conforme Coelho et al. (2004), o coque, apesar de se mostrar viável economicamente para a indústria, suas propriedades e características precisam ser levadas em consideração no que se refere ao meio ambiente e à saúde do homem. Isto porque, dentre suas características, tem-se a composição quase que totalmente de carbono fixo e moléculas de hidrocarbonetos de alto peso molecular.

Além disso, também é possível evidenciar, por meio dos dados coletados na Empresa Alfa, as emissões da coqueificação por tonelada de carvão na Tabela 13. 
Tabela 13 - Emissões da coqueificação por tonelada de carvão

\begin{tabular}{cc}
\hline PRODUTO & MASSA (KG) PARA 1000 KG DE CARVÃO \\
\hline Coque & 624 \\
Alcatrão & 29,5 \\
$\mathrm{CO}$ & 22 \\
$\mathrm{CO} 2$ & 3,9 \\
$\mathrm{CH} 4$ & 87 \\
$\mathrm{C} 2 \mathrm{H} 4$ & 4,6 \\
$\mathrm{O} 2$ & 0 \\
$\mathrm{H} 2$ & 182 \\
$\mathrm{~N} 2$ & 4 \\
$\mathrm{H} 2 \mathrm{~S}$ & 1,2 \\
NH3 & 1,5 \\
HCN & 2,67 \\
Benzol & 21,3 \\
Óleos leves & 10,01 \\
S. de amônio & 11,23 \\
\hline
\end{tabular}

Fonte: Elaborado pelo autor

Dentre as emissões resultantes da coqueificação, conforme constatado, tem-se dentre outros, o alcatrão e o benzol. Sobre o alcatrão, Catonho (2013) enfatiza que este é formado por hidrocarbonetos aromáticos que, quando se apresentam em elevadas concentrações se tornam prejudiciais à saúde humana, pois se tornam carcinogênicos. Devido a isso, o alcatrão deve ser evitado quanto ao contato com a pele.

Sobre o benzol, Catonho (2013) explica que este possui um mecanismo de ação tóxica que pode causar câncer no homem.

A Figura 9 é referente à coqueificação é análogo ao carvão vegetal, conforme pode ser verificado. 
Figura 9 - Massa de gás em $\mathrm{kg}$ por tonelada de carvão mineral beneficiado na coqueificação

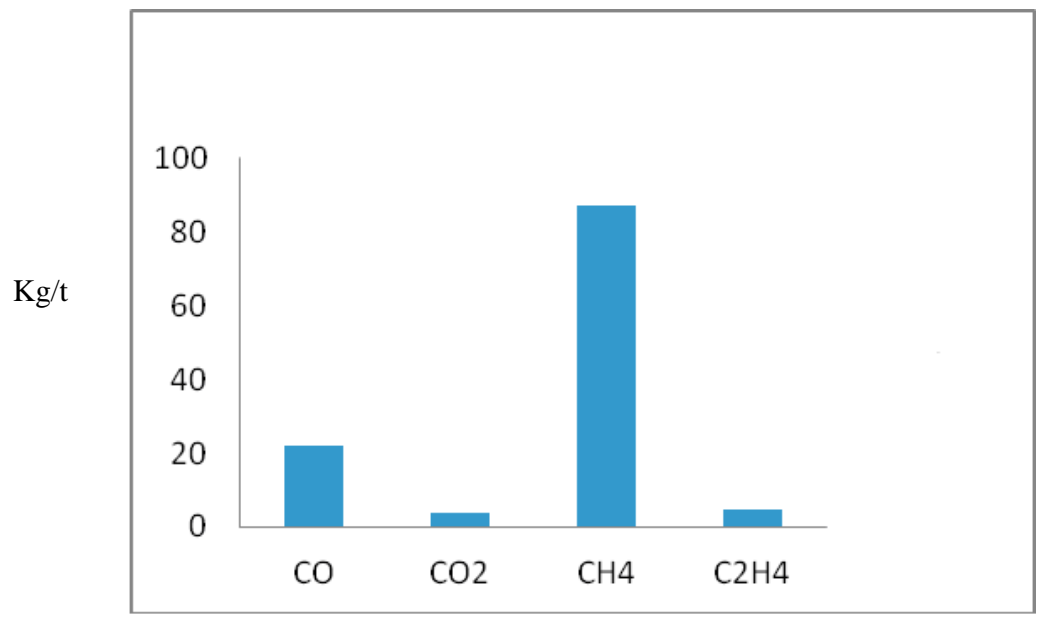

Fonte: Elaborado pelo autor

A partir das informações coletadas na Empresa Alfa, pode-se constatar que produtos voláteis como $\mathrm{CO}, \mathrm{CO}_{2}, \mathrm{CH}_{4}$ e $\mathrm{C}_{2} \mathrm{H}_{4}$ são produzidos em maior quantidade atingindo valores da ordem de 214,5 $\mathrm{kg}$ por tonelada de madeira no beneficiamento do carvão vegetal contra $117,5 \mathrm{~kg}$ para o carvão mineral. Contudo, o coque gera poluentes muito nocivos ao meio ambiente como $\mathrm{HCN}$ e $\mathrm{H}_{2} \mathrm{~S}$, diferente do carvão vegetal que não o faz.

Segue representada na Tabela 14 as emissões da coqueificação com cada substância diferenciada por letra minúscula e em seguida é apresentada a Matriz de Leopold com a indicação da magnitude e importância dos impactos gerados por cada substância emitida. Contudo, deve-se destacar que, conforme exposto na literatura por Coelho et al. (2004), as substâncias emitidas com a coqueificação são compostas quase que completamente de carbono fixo e algumas moléculas de hidrocarbonetos de alto peso molecular. 
Tabela 14 - Diferenciação por letras minúsculas das substâncias emitida na coqueificação

\begin{tabular}{cc}
\hline PRODUTO & MASSA (KG) PARA 1000 KG DE CARVÃO \\
\hline Coque & 624 \\
Alcatrão & $29,5 \mathrm{x}$ \\
$\mathrm{CO}$ & $22 \mathrm{y}$ \\
$\mathrm{CO} 2$ & $3,9 \mathrm{z}$ \\
$\mathrm{CH} 4$ & $87 \mathrm{a}$ \\
$\mathrm{C} 2 \mathrm{H} 4$ & $4,6 \mathrm{~b}$ \\
$\mathrm{O} 2$ & 0 \\
$\mathrm{H} 2$ & $182 \mathrm{c}$ \\
$\mathrm{N} 2$ & 4 \\
$\mathrm{H} 2 \mathrm{~S}$ & $1,2 \mathrm{~d}$ \\
$\mathrm{NH} 3$ & $1,5 \mathrm{e}$ \\
HCN & $2,67 \mathrm{f}$ \\
Benzol & $21,3 \mathrm{~g}$ \\
Óleos leves & $10,01 \mathrm{~h}$ \\
S. de amônio & $11,23 \mathrm{i}$ \\
\hline
\end{tabular}

Fonte: Dados da pesquisa.

As letras minúsculas colocadas ao lado dos valores da tabela serão usadas na tabela de resultados para indicar tanto magnitude quanto importância dos impactos gerados por cada substância.

$\mathrm{Na}$ Tabela 15 é possível observar a classificação de cada constituinte emitido na coqueira quanto aos impactos gerados.

Tabela 15 - Classificação de cada constituinte emitido na coqueria

\begin{tabular}{ccccccccc}
\hline Tipo de & \multirow{2}{*}{ Impacto } & Meio afetado & \multicolumn{3}{c}{ Magnitude } & \multicolumn{3}{c}{ Importância } \\
\cline { 2 - 8 } & & $\mathrm{P}$ & $\mathrm{M}$ & $\mathrm{G}$ & 1 & 2 & 3 \\
\hline \multirow{3}{*}{ Positivo } & físico & $\mathrm{b}, \mathrm{e}, \mathrm{f}$ & & $\mathrm{c}$ & & $\mathrm{b}$ & $\mathrm{c}, \mathrm{e}, \mathrm{f}$ \\
& biótico & & & & & & \\
& antrópico & & & & & & \\
& físico & $\mathrm{z}, \mathrm{d}$ & $\mathrm{y}$ & $\mathrm{a}$ & & $\mathrm{a}$ & $\mathrm{y}, \mathrm{z}, \mathrm{d}$ \\
Negativo & biótico & $\mathrm{h}, \mathrm{i}$ & $\mathrm{x}, \mathrm{g}$ & & $\mathrm{h}$ & $\mathrm{g}, \mathrm{i}$ & $\mathrm{x}$ \\
& antrópico & & & & & & \\
\hline
\end{tabular}

Fonte: Elaborado pelo autor 
Obs: A repetição de letras minúsculas na tabela indica que mais de uma substância possui a mesma classificação tanto na magnitude quanto na importância.

-Meio físico: meio ambiente +meio modificado pelo homem.

-Meio biótico: meio ambiente.

-Meio Antrópico: meio modificado pelo homem

A Tabela 16 apresenta as emissões e a matriz de Leopold para o beneficiamento do carvão vegetal.

Tabela 16 - Diferenciação por letras minúsculas das substâncias emitidas no beneficiamento do carvão vegetal

\begin{tabular}{|c|c|}
\hline $\begin{array}{c}\text { PRODUTOS E EMISSÕES DA } \\
\text { CARBONIZAÇÃO }\end{array}$ & $\begin{array}{c}\text { MASSA EM KG POR } \\
\text { TONELADA DE LENHA (BASE } \\
\text { SECA) }\end{array}$ \\
\hline Carvão & 299 \\
\hline Ácido Pirolenhoso & $355 x$ \\
\hline Ácido Acético & $50 \mathrm{y}$ \\
\hline Metanol & $20 \mathrm{z}$ \\
\hline Alcatrão Solúvel & $67^{\mathrm{a}}$ \\
\hline Água E Outros & $157 b$ \\
\hline Alcatrão Insolúvel & $69 c$ \\
\hline Gases Não Condensáveis & $158 \mathrm{~d}$ \\
\hline $\mathrm{H} 2 \quad 0,63 \%$ & $1,4 \mathrm{e}$ \\
\hline $\mathrm{CO} 34 \%$ & $76 f$ \\
\hline $\mathrm{CO}_{2} 62 \%$ & $134 \mathrm{~g}$ \\
\hline CH4 2,43\% & $4 h$ \\
\hline Etano $0,13 \%$ & $0,5 \mathrm{i}$ \\
\hline Outros $0,81 \%$ & 2,5 \\
\hline
\end{tabular}

Fonte: Elaborado pelo autor

A Tabela 17apresenta a Classificação de cada constituinte emitido no beneficiamento do carvão vegetal, conforme segue. 
Tabela 17 - Classificação de cada constituinte emitido no beneficiamento do carvão vegetal

\begin{tabular}{ccccccccc}
\hline Tipo de & \multirow{2}{*}{ Impacto } & Meio afetado & \multicolumn{3}{c}{ Magnitude } & \multicolumn{3}{c}{ Importância } \\
\cline { 2 - 7 } Positivo & físico & $\mathrm{e}$ & $\mathrm{e}, \mathrm{i}$ & & & $\mathrm{i}$ & & $\mathrm{e}$ \\
& biótico & & $\mathrm{y}$ & $\mathrm{x}, \mathrm{b}$ & $\mathrm{y}$ & $\mathrm{x}$ & $\mathrm{b}$ \\
& antrópico & & & & & & \\
& físico & $\mathrm{h}$ & & $\mathrm{d}, \mathrm{f}, \mathrm{g}$ & & $\mathrm{h}$ & $\mathrm{d}, \mathrm{f}, \mathrm{g}$ \\
Negativo & biótico & & $\mathrm{z}, \mathrm{a}, \mathrm{c}$ & & $\mathrm{c}$ & $\mathrm{z}$ & $\mathrm{a}$ \\
& antrópico & & & & & & \\
\hline
\end{tabular}

Fonte: Elaborado pelo autor

Obs: A repetição de letras minúsculas na tabela indica que mais de uma substância possui a mesma classificação tanto na magnitude quanto na importância.

-Meio físico: meio ambiente +meio modificado pelo homem.

-Meio biótico: meio ambiente.

-Meio Antrópico: meio modificado pelo homem

Rosa (2010) explica que o processo de beneficiamento do carvão vegetal gera expressiva quantidade de poluentes, tais como ácido acético, metanol, alcatrão solúvel e insolúvel e outros.

Diante dos dados analisados na Empresa Alfa para a avaliação econômico-ambiental da substituição do coque utilizado em alto-forno em uma indústria siderúrgica, nota-se a necessidade de se avaliar os custos e impactos das opções de modo que seja possível atender às necessidades da empresa sem agredir o meio ambiente.

É importante destacar que os seres vivos sempre buscaram formas para garantir a própria sobrevivência e, referente aos seres humanos, estes possuem a capacidade criativa que permitiu a eles desenvolverem uma relação mais incisiva e transformadora sobre o meio em que vivem. É dever de todos, sociedade, empresas, governos, organizações não governamentais, comunidades e universidades, incentivar a sustentabilidade nas ações cotidianas, encontrando soluções para os problemas pessoais, sociais e ambientais por meio do desenvolvimento sustentável.

Conforme Moreira (2009), a sustentabilidade também assegura o sucesso do negócio em longo prazo e, ao mesmo tempo, contribui para o desenvolvimento econômico e social da comunidade promovendo um meio ambiente saudável e uma sociedade estável. 
Dentre as leis existentes como proteção ao meio ambiente, pode-se verificar que na Legislação Ambiental, são diversas as leis existentes para a proteção e promoção do meio ambiente os quais se fazem presentes os seguintes assuntos: a Lei 6.902/1981 (Dispõe sobre a criação de Estações Ecológicas, Áreas de Proteção Ambiental e dá outras providências); a Lei 6.938/1981 (dispõe sobre a Política Nacional do Meio Ambiente, seus fins e mecanismos de formulação e aplicação, e dá outras providências); a Lei 9.605/1998 (trata das sanções penais e administrativas derivadas de condutas e atividades lesivas ao meio ambiente, e dá outras providências); e a Resolução CONAMA 313/2002 (dispõe sobre o "Inventário Nacional de Resíduos Sólidos Industriais"). Tais leis devem ser respeitadas e aplicadas em todos os segmentos industriais. 


\section{CONCLUSÃO}

Com base nos resultados, concluiu-se que ao se avaliar econômico-ambiental a substituição do coque utilizado em alto-forno, em termos econômicos, o custo de utilização do gás natural é mais viável que o coque, pois, o gasto para se produzir 1 tonelada de gusa com ele é de $\mathrm{R} \$ 27,00$ contra $\mathrm{R} \$ 123,70$ do coque.

Nota-se que o gás natural em comparação ao coque apresenta um valor muito inferior o que torna interessante considerá-lo para a produção do ferro gusa e analisar de que forma o coque poderia ser de fato viável em termos econômicos.

Em termos de impactos ambientais, o gás natural não gera substâncias voláteis, pois, não passa por processo de beneficiamento químico. Em comparação com o coque, que gera muitos efluentes tanto líquidos quanto gasosos, o gás natural é um combustível mais viável ambientalmente que o coque. Assim sendo, o gás natural é uma alternativa econômica e ambiental mais viável que o coque.

Em termos econômicos, o carvão vegetal é inviável em relação ao coque, pois, a sua utilização para a produção de 1 tonelada de gusa em alto forno varia de $\mathrm{R} \$ 135,50$ a $\mathrm{R} \$ 176,85$ enquanto que a utilização do coque para a mesma tonelada é de $\mathrm{R} \$ 123,70$ no alto forno 2. Operar o alto forno 2 com a utilização do coque é economicamente mais viável que operá-lo com carvão vegetal.

Entre o coque e o carvão vegetal, a viabilidade econômica é favorável à utilização do coque para produção de ferro gusa, ainda que a diferença é pouca. Neste caso, avaliar as demais características de ambos seja importante para verificar se de fato apenas os custos seja motivo para a escolha entre um ou outro.

Em termos de impactos ambientais, apesar de o carvão vegetal gerar maior quantidade de substâncias voláteis como $\mathrm{CO}, \mathrm{CO}_{2}, \mathrm{CH}_{4} \mathrm{e}$ $\mathrm{C}_{2} \mathrm{H}_{4}$, ele não gera substâncias tóxicas a base de enxofre como $\mathrm{H}_{2} \mathrm{~S}$ e $\mathrm{HCN}$.

Por meio de um balanço geral, apesar de o carvão vegetal ser inviável economicamente em relação ao coque a margem de diferença de preço não é significativa fazendo a sua viabilidade ambiental se sobreponha à viabilidade financeira fazendo com que ele ainda assim seja mais viável que o coque.

Contudo, seja qual for a escolha, durante a fase de produção pode haver impactos negativos ou positivos no meio ambiente e nesse contexto, considerando a substituição do coque na produção de ferro 
gusa, no meio físico os impactos negativos podem ser maiores, de acordo com a pesquisa realizada.

No meio físico, verificou-se que o impacto negativo aparece em maior proporção em comparação ao impacto positivo.

Também no meio biótico é possível perceber que ele é muito afetado negativamente quando da substituição do coque utilizado em alto-forno para obtenção do ferro gusa.

De um modo geral, em termos ambientais, é importante que a empresa tenha uma Gestão Ambiental eficiente, pois, trata-se da administração das atividades econômicas e sociais que têm o objetivo de fazer uso consciente e racional dos recursos naturais. Uma adequada Gestão Ambiental precisa ter foco no desenvolvimento de práticas que asseguram a preservação e conservação da biodiversidade, minimizando o impacto ambiental por meio da sustentabilidade.

\subsection{TRABALHOS FUTUROS}

Para um futuro projeto deve ser realizado um estudo da viabilidade econômica de implantação de autos fornos que operem com a utilização de gás natural e carvão vegetal no lugar de autos fornos que operem com coque. Bem como os custos de manutenção destes alto fornos em relação aos autos fornos de coque. 


\section{REFERÊNCIAS}

AFONSO, J.C; PEREIRA, K.S. Análise de compostos sulfurados em efluentes gasosos de refinaria de petróleo. Quím. Nova, São Paulo, v. 33, n. 4, p. 957-963, 2010.

ALMEIDA, S. L. M.; LUZ, A.B; SAMPAIO, J.A. Tratamento de Minérios. Rio de Janeiro: CETEM, 2004.

ALVES, H. J.; MELCHIADES, F. G.; BOSCHI, A. O.. Consumo de gás natural na indústria de revestimentos cerâmicos brasileira. Cerâmica, São Paulo, v. 54, n. 331, p. 326-331, set. 2008.

ANDRADE, M. L. A.; CUNHA, L. M. S. O setor siderúrgico. 2005. Disponível em:

<http://www.ourinhos.unesp.br/gedri/biblioteca/outros/artigos/andrade_ 01.pdf $>$. Acesso em: 21 abr. 2015.

ARAUJO, E.S ; MARSOLA, T ; MIYAZAWA, M.; SOARES, L.H. de B.; URQUIAGA, S.; BODDEY, R.M.; ALVES, B.J.R. Calibração de câmara semiaberta estática para quantificação de amônia volatilizada do solo. Pesq. agropec. bras., Brasília, v. 44, n. 7, p. 769776, jul. 2009.

ARAÚJO, L. A. Manual de Siderurgia. São Paulo: Arte e Ciência, 1997.

ASSIS, C.F.C. Caracterização de carvão vegetal para a sua injeção em altos-fornos a carvão vegetal de pequeno porte. $2008.138 \mathrm{f}$. Dissertação (Mestrado em Engenharia de Materiais) - Redemat, Ouro Preto.

BARCELLOS, D.C. Forno container para produção de carvão vegetal: desempenho, perfil térmico e controle de poluição. 2002. 85f. Tese (Doutorado em Ciência Florestal) - Universidade Federal de Viçosa, Viçosa.

BECHELLI, C. B. Utilização de matriz de impactos como ferramenta de análise em estudos de impacto de vizinhança: edifício residencial em 
Porto Rico - PR. In: XVI Encontro Nacional dos Geógrafos, Porto Alegre. 2010.

BNDS - Banco Nacional de Desenvolvimento Econômico e Social. Siderurgia no Mundo. 2014. Disponível em: <http://www.bndes.gov.br/SiteBNDES/bndes/bndes_pt/Institucional/Pu blicacoes/Consulta_Expressa/Tipo/BNDES_Setorial/199703_9.html>. Acesso em: 25 abril. 2015.

BORTOLI, M; KUNZ, A; SOARES, H.M; BELLI FILHO, P; COSTA, R.H.R. Emissão de óxido nitroso nos processos de remoção biológica de nitrogênio de efluentes. Eng. Sanit. Ambient., Rio de Janeiro, v. 17, n. 1, p. 01-06, mar. 2012.

BRASIL, H.G. Avaliação moderna de investimentos. Rio de Janeiro: Qualitymark, 2002.

BRASIL. MINISTÉRIO DO MEIO AMBIENTE - MMA.

Disponível em: <http//:www.mma.gov.br>. Acesso em: 1 mai. 2015.

BRASIL. Resolução CONAMA 382:2006. Disponível em:

$<$ http://www.ambientedomeio.com/2007/07/29/conceito-meioambiente/>. Acesso em: 28 abr. 2015.

CABRELON, M. D; PEREIRA, A.H.A; MEDEIROS, J; TOLEDOFILHO, R.D; RODRIGUES, J.A. Efeito do tempo de exposição a uma atmosfera coqueificante na microestrutura e nas propriedades de um concreto refratário usado na indústria petroquímica. Cerâmica, São Paulo, v. 58, n. 346, p. 195-204, jun. 2012.

CALDAS, J.A.C. Análise de duas rotas tecnológicas na siderurgia brasileira com foco na eficiência energética. 2011. 49f. Monografia (Curso de Engenheiro de Produção) - Faculdade de Engenharia da Universidade Federal de Juiz de Fora.

CALFA, B.A; TOREM, M.L. Biorreagentes: aplicações na remoção de metais pesados contidos em efluentes líquidos por biossorção/bioflotação. Rem: Rev. Esc. Minas, Ouro Preto, v. 60, n. 3, p. 537-542, set. 2007. 
CAMIOTO, F.C; REBELATTO, D. A.N. Assessment of the environmental contribution by changing the energy matrix of the brazilian pig iron and steel sector. Gest. Prod., São Carlos, v. 21, n. 4, p. 732-744, dez. 2014.

CNI - Confederação Nacional da Indústria. A indústria do aço no Brasil. Brasília: CNI, 2012.

CARPIO, R.C; SILVA, R.J; JORGE, A.B. Otimização da mistura de combustíveis secundários alternativos visando atender as restrições operacionais e ambientais em fornos de cimenteiras. XXXV SBPO, A pesquisa Operacional e os Recursos Renováveis, 4 a 7 de novembro de 2003, Natal-RN.

CARNEIRO, L. F. S. Avaliação do comportamento da mistura de casca de arroz e carvão mineral na granulometria de 100 a 200mesh para sua injeção em altos-fornos. 2012. 56f. Monografia (Curso de Engenharia Metalúrgica) - Escola de Minas da Universidade Federal de Ouro Preto, Ouro Preto.

CARVALHO, S.J.P; DIAS, A.C.R; SHIOMI, G.M; CHRISTOFFOLETI, P.J. Adição simultânea de sulfato de amônio e ureia à calda de pulverização do herbicida glyphosate. Planta daninha, Viçosa, v. 28, n. 3, p. 575-584, 2010.

CATONHO, H.S. Estudo do processo de combustão in-situ em reservatórios maduros de óleos médios e leves (High Pressure Air Injection). 2013. 185f. Dissertação (Mestrado em Ciência e Engenharia de Petróleo) - Universidade Federal do Rio Grande do Norte.

CAVALCANTI, P.P.S. Gestão ambiental na indústria siderúrgica aspectos relacionados às emissões atmosféricas. 2012. 54f.

Monografia (Curso de Engenharia Metalúrgica) - Universidade Federal do Rio de Janeiro.

CEMIN, D.S. Desenvolvimento de um forno para carbonização de resíduos agroflorestais em pequena escala. 2010. 82f. Dissertação (Mestrado em Ciências Florestais) - Faculdade De Tecnologia - FT.

COELHO, R.J ; SILVA, O.J; ALVES, M.T; ANDRADE, L.A; ASSIS, P.S. Modelos de previsão da qualidade metalúrgica do coque a partir da 
qualidade dos carvões individuais e do coque obtido no forno-piloto de coqueificação. Rem: Rev. Esc. Minas, Ouro Preto, v. 57, n. 1, p. 27 32, mar. 2004.

COSTA, M. M. Princípios de ecologia industrial aplicados à sustentabilidade ambiental e aos sistemas de produção de aço. Tese de Doutorado, PPE/COPPE- UFRJ, Rio de Janeiro, 2002.

EPE - Empresa de Pesquisa Energética. Caracterização do Uso da Energia no Setor Siderúrgico. 2009. Rio de Janeiro. Disponível em <http://www.epe.gov.br/mercado/Documents/S\%C3\%A9rie\%20Estudos \%20de\%20Energia/20090430_2.pdf>. Acesso em: 17 abr. 2015.

FELIX, E.P; CARDOSO, A.A. Amônia (NH3) atmosférica: fontes, transformação, sorvedouros e métodos de análise. Quím. Nova, São Paulo, v. 27, n. 1, p. 123-130, Feb. 2004.

FIGURA 4. Desenfornamento do coque nos fornos. Disponível em: $\langle$ http//:www.cesec.ufpr.br $>$. Acesso em: 2 mai. 2015.

FREITAS, L. A. de; SÁNCHEZ, R.; VIEIRA, C. M. F. Incorporação de coque de petróleo em cerâmica vermelha. Cerâmica, v. 57, n. 342, p. 206-211, jun. 2011.

FREITAS, J.C.C. Estudo de materiais carbonosos obtidos por decomposição térmica de precursores orgânicos através de ressonância magnética nuclear de alta resolução em conjunção com outras técnicas experimentais. 2000. 189f. Tese (Doutorado em Física) - Centro Brasileiro de Pesquisas Físicas.

GARGANTINI, H.; FORSTER, R; SOBRINHO, A; COBRA NETTO, A. Ensaio de competição entre amônia anidra e sulfato de amônio, em cultura de milho. Bragantia, Campinas, v. 33, n. unico, p. 111-113, 1974.

GODOY, A. S. A pesquisa qualitativa e sua utilização em administração de Empresas. Revista de Administração de Empresas, São Paulo, v. 35, n. 4, p. 65-71, jul. /ago. 1995.

GOMES, F.M. História da Siderurgia no Brasil. Belo Horizonte: Itatiaia e São Paulo, Editora da Universidade de São Paulo, 2006. 
GUERRA, S.M; CARVALHO, A. V. Um paralelo entre os impactos das usinas hidrelétricas e termoelétricas. Rev. adm. empres., São Paulo , v. 35, n. 4, p. 83-90, ago. 1995.

GUILHERME, V.S; CASTRO, J.A. Utilização de gás de coqueria na sinterização de minério de ferro. Rem: Rev. Esc. Minas, Ouro Preto, v. 65, n. 3, p. 357-362, Sep. 2012.

IBS - Instituto Brasileiro de Siderurgia. A Siderurgia em Números. 2009. Rio de Janeiro. Disponível em:

<http://www.ibs.org.br/siderurgia_historia_brasill.asp>. Acesso em: 25 abr. 2015.

IBS - Instituto Brasileiro De Siderurgia. História da Siderurgia: a Siderurgia no Brasil. 2008. Rio de Janeiro. Disponível em: <http://www.ibs.org.br/siderurgia_historia_brasil1.asp>. Acesso em: 15 abr. 2015.

JACOMINO, V.M.F; BATISTA, A.A.M; RIBEIRO, E.D.L; CASTRO, L.F.A. Controle ambiental das indústrias de ferro-gusa em altosfornos a carvão vegetal. Belo Horizonte: Projeto Minas Ambiente, 2002.

JOAQUIM, M.S. Carvão vegetal: uma alternativa para os produtos rurais do sudoeste Goiano. 2009. 97f. Dissertação (Mestrado em Engenharia Florestal) - Faculdade de Tecnologia da Universidade de Brasília, Brasília.

LEAL, T.E. Produção de Carvão Vegetal através de micro-ondas. 2012. 53f. Monografia (Curso de Engenharia Metalúrgica) - Escola de Minas da Universidade Federal de Ouro Preto, Ouro Preto.

LEE, K; LIM, H; KIM, H. A study of the status of exposure to polycyclic aromatic hydrocarbons (PAHs) in relation to its metabolites among workers in a Korean chemical factory. Ciênc. saúde coletiva, Rio de Janeiro, v. 19, n. 12, p. 4809-4818, dez. 2014.

MACIEL, A.S; ANDRADE, A.M; ALBUQUERQUE, C.E.C. Procedimento para extração e utilização de fenóis do alcatrão vegetal na 
produção de adesivos fenólicos. Revista Floresta e Ambiente, v. 1, n. 3, p. 86-96, 1996.

MALINOWSKI, S.A. Pintura em ambientes imersos de usinas hidrelétricas utilizando tintas livres de alcatrão de hulha. 2012. 123f. Dissertação (Curso de Desenvolvimento de Tecnologia) - Instituto de Engenharia do Paraná, Curitiba.

MARIANO, A.P; SILVA, ARIOVALDO, J; OLIVEIRA, V.J.A; ANGELIS, D.F. Avaliação da dispersão de efluente líquido de refinaria de petróleo. Eng. Sanit. Ambient., Rio de Janeiro , v. 15, n. 3, p. 251256, Sept. 2010 .

MARTINEZ, D. B. Transporte de Gás Natural sob a forma de hidratos gasosos. 2009. 107f. Projeto (Curso de Engenheiro Químico) Programa Escola de Química/Agência Nacional de Petróleo, Gás Natural e Biocombustíveis, Rio de Janeiro.

MORAES, F.F. Alto-Forno Sustentável: o mercado de carbono no Brasil com ênfase na produção de gusa a partir de carvão vegetal de florestas plantadas de eucalipto. 2008. 185f. Dissertação (Mestrado em Engenharia Química) - Universidade Federal de Minas Gerais, Belo Horizonte.

MOREIRA, C.F. Sustentabilidade de sistemas de produção de café sombreado orgânico e convencional. 2009. 146f. Tese (Doutorado em Ecologia Aplicada) - Universidade de São Paulo.

MOREIRA, I. V. D. Origem e Síntese dos Principais Métodos de Avaliação de Impacto Ambiental (AIA). São Paulo: CETESB, 1993.

MORELLO, T.F. Carvão vegetal e siderurgia: de elo perdido a solução para um mundo Pós-Kyoto. 2009. 171. Dissertação (Mestrado em Economia) - Universidade de São Paulo, São Paulo.

MOTA, A.C.F.V. Siderúrgicos no Brasil: a contribuição da avaliação ambiental estratégica no caso de Corumbá. Dissertação (mestrado) UFRJ/ COPPE/ Programa de Planejamento Energético, 2013. 
NAVARRO, A. F; PALLADINO, L.A. Degradación de Efluentes Líquidos Mediante Lechos Fluidizados. Inf. tecnol., La Serena, v. 20, n. 5, 2009.

OLIVEIRA, A.C; CARNEIRO, A.C.O; VITAL, B.R; ALMEIRA, W; PEREIRA, B.L.C; CARDOSO, M.T. Parâmetros de qualidade da madeira e do carvão vegetal de Eucalyptus pellita F. Muell. Sci. For., Piracicaba, v. 38, n. 87, p. 431-439, set. 2010.

OLIVEIRA, S.L.O. Tratado de Metodologia Científica: projetos de pesquisas, TGI; TCC, monografia, dissertações e teses. São Paulo: Pioneira, 1997.

PAVANI, R.H. Análise das vantagens e desvantagens no uso do gás natural em veículos de passeio. 2012. 88f. Dissertação (Mestrado em Engenharia Automotiva) - Centro Universitário Instituto Mauá de Tecnologia, São Caetano do Sul.

PEREIRA NETO, A; BRETZ, J.S; MAGALHÃES, F.S; MANSUR, M.B; ROCHA, S.D.F. Alternativas para o tratamento de efluentes da indústria galvânica. Eng. Sanit. Ambient., Rio de Janeiro, v. 13, n. 3, p. 263-270, set. 2008.

PIERONI, F. P.; GUERRA, S. M. G.; SANTOS, E. M., 2004. Estudo sobre as barreiras à penetração do gás natural na indústria siderúrgica brasileira. In: Congresso Brasileiro de Planejamento Energético, Itajubá. Anais. Itajubá: UNIFEI/SBPE, 2004.

PINHEIRO, P. C. C; VIANA E.; REZENDE, M.E.A., PINHEIRO, P.C.C.; SAMPAIO R.S. A produção de carvão vegetal: teoria e prática. Belo Horizonte: Editora UFMG, 2006.

POLICARPO, F.F. Minério de ferro: desafios para as indústrias mineral e siderúrgica. 2012. 64f. Monografia (Curso de Engenharia de Recursos Minerais) - Universidade Federal de Minas Gerais, Belo Horizonte.

PWC. Siderurgia no Brasil. 2013. Disponível em: <http//:www.pwc.com.br>. Acesso e: 3 mai. 2015. 
QUEIROZ, G.O. Otimização da injeção cíclica de vapor em reservatórios de óleo pesado. 2006. 135f. Dissertação (Mestrado em Engenharia Química) - Universidade Federal do Rio Grande do Norte, Natal.

RANGEL, L.P; BUCHLER, P.M. Estudo do nitrogênio na combustão do gás natural. Quím. Nova, São Paulo, v. 28, n. 6, p. 957-963, Dec. 2005.

REZENDE, M. E. Produção de carvão vegetal: importância do conhecimento fundamental. Belo Horizonte: Editora UFMG, 2006.

ROSA, R.A. Qualidade do carvão vegetal, para uso doméstico, comercializado em três municípios do estado do Espírito Santo. 2010. 64f. Monografia (Curso de Engenharia Industrial) - Universidade Federal do Espírito Santo, Espírito Santo.

ROSS, S.A.; WETERFILD, R. W.; JAFFE, J. F. Administração financeira. São Paulo: Atlas, 2002.

SAMPAIO, R. S. Produção de metais com biomassa plantada. Belo Horizonte: LabMídia, 2001.

SANGOI, L; ERNANI, P.R; LECH, V.A; RAMPAZZO, C.

Volatilização de N-NH3 em decorrência da forma de aplicação de uréia, manejo de resíduos e tipo de solo, em laboratório. Cienc. Rural, Santa Maria, v. 33, n. 4, p. 687-692, ago. 2003.

SANTOS, A.R. L ; AQUINO, S.F ; CARVALHO, C.F ; VIEIRA, L.A; GONTIJO, E.S.J. Caracterização e tratabilidade biológica dos efluentes líquidos gerados em cabines de pintura de uma indústria moveleira. Eng. Sanit. Ambient., Rio de Janeiro, v. 15, n. 4, p. 357-366, Dec., 2010 .

SANTOS, A.L. Inventário dos rejeitos, efluentes e sub-produtos das indústrias siderúrgicas integradas na fabricação de aço líquido. 2010. 79f. Inventário (Curso de Engenharia Metalúrgica) Universidade Federal do Rio de Janeiro, Rio de Janeiro. 
SANTOS, E.M; FAGÁ, M.T.W ; BARUFI, C.B ; POULALLION, P.L. Gás natural: a construção de uma nova civilização. Estud. av., São Paulo, v. 21, n. 59, p. 67-90, Apr. 2007.

SANTOS, S.F.O.M. Produção de carvão vegetal em cilindros metálicos verticais: alguns aspectos referentes à sustentabilidade. 2007. 95f. Dissertação (Mestrado em Engenharia de Produção) - Universidade Tecnológica Federal do Paraná, Paraná.

SILVA, A.L.E; MORAES, J.A.R; MACHADO, Ê.L. Proposta de produção mais limpa voltada às práticas de ecodesign e logística reversa. Eng. Sanit. Ambient., Rio de Janeiro, v. 20, n. 1, p. $29-$ 37, mar. 2015.

ULHOA, M.B. Conqueificação em baterias de fornos horizontais. São Paulo: ABM, 2005.

VALENTIM, L.T. Procedimento operacional para produção do piche eletrolítico, utilizado no setor siderúrgico. 2013. 81f. Dissertação (Mestrado em Materiais) - Centro Universitário de Volta Redonda, Volta Redonda.

VERGARA, S. C. Projetos e relatórios de pesquisa em administração. São Paulo: Atlas, 2006.

VITAL, M.H.F; CABRAL PINTO, M.A. Condições para a sustentabilidade da produção de carvão vegetal para fabricação de ferrogusa no Brasil. Siderurgia, BNDES Setorial, v. 30, n. 1, p. 237-297, 2014.

WEBER, C.C; CYBIS, L.F; BEAL, L.L. Reúso da água como ferramenta de revitalização de uma estação de tratamento de efluentes. Eng. Sanit. Ambient., Rio de Janeiro, v. 15, n. 2, p. 119-128, jun. 2010.

YIN, R.K. Estudo de caso: planejamento e métodos. Porto alegre: Bookman, 2001. 
